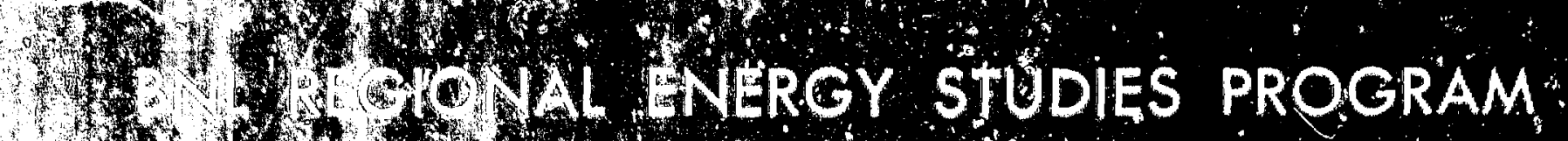
that $3+2 y$

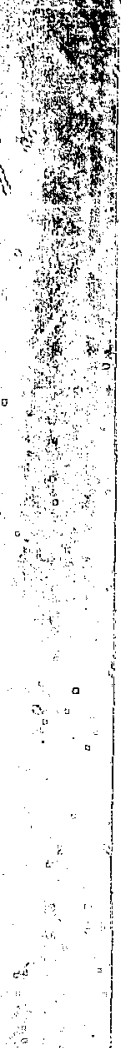

is

BAL 22806

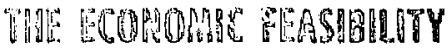

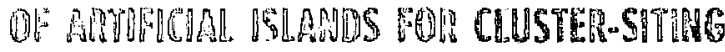

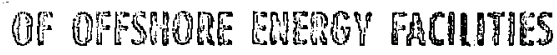

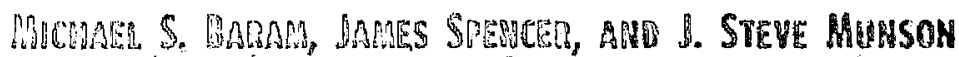

Amri] 1977

is

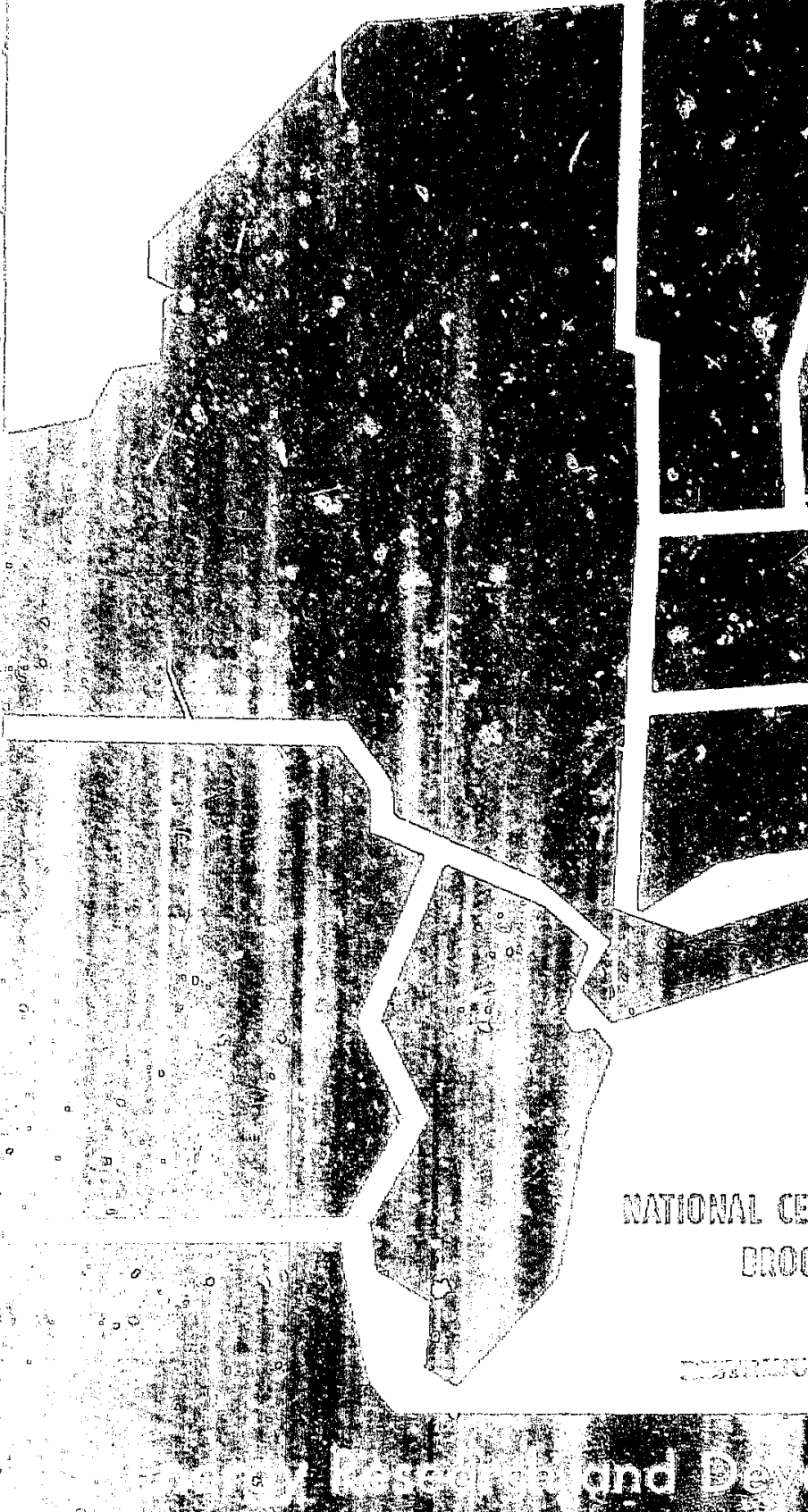

BOALC ARALPS DUVSION

MASTER

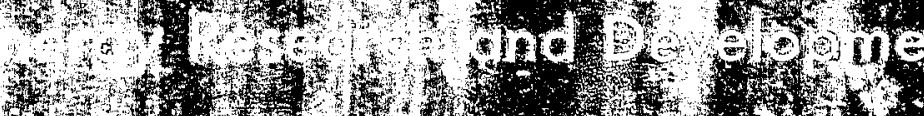

UPDOR, REW YORK 11973 


\title{
THE ECONOMIC FEASIBILITY OF ARTIFICIAL ISLANDS FOR CLUSTER-SITING OF OFFSHORE ENERGY FACILITIES
}

Michael S. Baram and James Spencer

Department of Civil Engineering Massachusetts Instifute of Technology

Cambridge, Massachusetts 02139

\author{
J. Steve MUnSON \\ Policy Analysis Division \\ Mational Center for Analysis of Energy Systems
}

April 1977

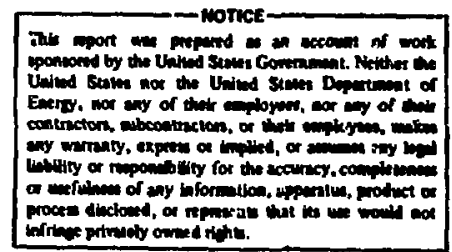

POLICY ANALYSIS DIVISION

NATIONAL CEMTER FOR ANALYSIS OF ENERGY SYSTEMS

BROOKHAGEN MATIONAL LABORATORY

ASSOCIATED UNIVERSITIES, INC.

UPTOH, NEW YORK 11973

Prepared for the

DIVISION OF BIOMEDICAL AND ENVIRONMENTAL RESEARCH

UNITED STATES ENERGY RESEARCH AND DEVELOPMENT ADMMNISTRATIOH

UHDER CONTRACT MO. EY-76-C-02-0016 
NOT I CE

This report was prepared as an account of work sponsored by the United States Government. Neither the United States nor the United States Energy Research and Development Administration, nor any of their employees, nor any of their contractors, subcontractors, or their employees, makes any warranty, express or implied, or assumes any legal liability or responsibility for the accuracy, completeness or usefulness of any information, apparatus, product or process disclosed, or represents that its use would not infringe privately owned rights.

Printed in the United States of America

Available from

National Technical Information Service

U.S. Department of Commerce

5285 Port Royal Road

Springfield, VA 22161

Price: Printed Copy \$5.00; Microfiche $\$ 3.00$

June 1977

235 copies 
With increasing demand for electricity and energy the siting of energy facilities assumes great importance. Recent developments in siting energy facilities onshore indicates that regulatory requirements, public particlpation in the siting process, and environmental and safety restrictions are imposing an expensive and of ten prohibitive burden on developers seeking to site energy facilicles. This study examines the economic and technical feasibility of developing offshore islands as an alternative to onshore facility development. It examines the technical and economic requirements of constructing artificlal islands for the siting of nuclear power plants, petroleum refinerles, deepwater ports and a multiple-fac1lity complex and compares these to requirements for the onshore development of similar facilities. The study discusses considerations for the sharing of an island site for multiple facilities and some of the financing alternatives which should be considered prior to implementing the offshore artificlal island alternative. 
FOREWORD

This report is one of a continuing serles of policy analysis studies in the area of energy facility siting prepared by the Brookhaven National Laboratory Regional Energy Studies Program, sponsored by the Division of Technology Overview, U.S. Energy Research and Development Administration. The intent of the analysis component is to prepare assessments appropriate to the regional scale of energy analysis. This contribution, prepared in coordination with consultants to the Reglonal Energy Studies Program explores the technical and economic feasibility of offshore lalands for energy facilities.

Other reports in this series on energy facility siting include:

T. Backstrom and M. Baram, "Artificial Islands for Cluster Siting of Dffshore Energy Facilities: An Assessment of the Legal and Regulatory Framework," BNL-50566 (June 1976).

P. Meler, "Energy Facility Location: A Regional Viewpoint," BNL-20423 (May 1975).

R. Church and J. Cohon, "Multiobjective Location Analysis of Regional Energy Facility Siting Problems," BNL-50567 (October 1976).

P. Meler, Editor, "A Preliminary Assessment of a Hypothetical Nuclear Energy Center in New Jersey," BNL-50465 (Nov. 1975).

P. Meler and D. Morell, "Issues in Clustered Nuclear Siting: A Comparison of a Hypothetical Nuclear Energy Center in New Jersey with Dispersed Nuclear Siting," BNL-50561 (Sept. 1976). 
CHAPTER

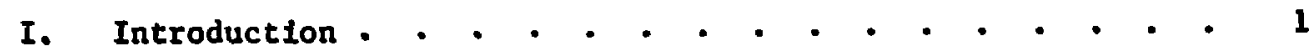

II. Method for Assessing Economic Feasibility - • • . • ${ }^{-} 3$

Ideal Assessment Method . • • . . • • - • • • 4

Selection of Priority Facilities - • • • • • • • 5

Onshore-Offshore Comparison for Each Facility. . . . 7

Comparison of Clustered and Dispersed Siting • • . . 8

Cluster Site Selection . • • . . • • • . . . 9

Choice of Optimum Cluster Site. . . . . . . . . 9

Choice of Financial Alternative . . . . . . . . 9

Application of Method . . . . . . . . . . 10

III. Offshore Structures for Energy Facilities . . . . . . 11

Artificial Islands . . . . . . . . . . . . 11

The Polder Method . . . . . . . . . . . . 11

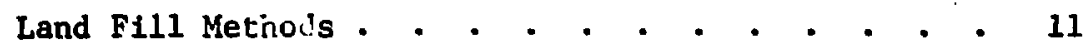

Beach Sea Island . . . . . . . . . . . . 12

Land Fill Island With Sea Defense Wall . . . . . 14

Dike and Fill Method . . . . . . . . . . . 14

Variations . . . . . . . . . . . . . . 14

Recent Artificial Island Projects and Proposals . . . 14

Bolsa Island. . . . . . . . . . . . . . 16

University of Delaware Study . . . . . . . . 18

Mining and Drilling Islands . . . . . . . . 19

Island Transhipment Terminals . . . . . . . . 19

Recreational Islands . . . . . . . . . . . 21

Cost of Artificial Island Construction . . . . . . 22

Deepwater Ports . . . . . . . . . . . . . 24

Deepwater Port Alternatives . . . . . . . . 24

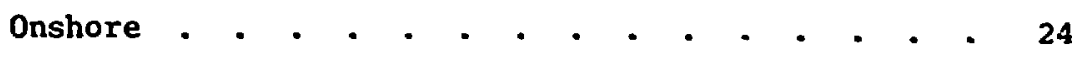

offshore . . . . . . . • . . • . . . . 26

Single Point Mooring - . . • . . . . . . 26

Single Anchor Leg Mooring - . - . . . . . 26

Conventional Moorlng Buoy . . . . . . . . 26 
Single Polnt Nooring Pler. . . . . . . . . . 28

Floating Platform . . . . . . . . . . . . 28

Artificlal Island . . . . . . . . . • . . 28

Comparison of offshore Deepwater Port Alternatives . . 28

IV. Cost Comparison of Onshore and Offshore Energy Facilitles - 33

Cost Feasibility of Offshore Nucl ear Power . . . . . 34

Indirect Contributions to Cost . . . . . . . . . 38

Total Plant Capital Costs . . . . . . . . . 40

Total Plant Costs . . . . . . . . . . . . 40

Transmission . . . . . . . . . . . . 40

Land and Shore Facilities. . . . . . . . . . 42

Thermal Cooling System . . . . . . . . . . 43

Other Environmental Controls . . . . . . . . . 43

Operating and Maintenance Ccsts . . . . . . . . 44

Total Nuclear Plant Costs and Summary

of Cost Comparison . . . . . . . . . . 44

Cost Comparison of offshore and Onshore Deepwater Ports . 44

Comparison With Existing or In-Construction Facilities 46

Comparison of Costs of Offshore Alternatives. • . . 49

Cost Comparison of Onshore and offshore 0il Rerinerles . 52

Refinery Plant . . . . • . . . . . . . . 52

Land Costs and Onshore Facilities . . . . . . . 54

Site Preparation. . . . . . . . . . . . . 54

Crude 011 Transport Pipeline . . . . . . . . . 55

Finished Product Transport Pipeline . . . . . . 55

Cost Comparison Conclusions . . . . . . . . . 55

Additional Constraints to 011 Refineries . . . . . 55

v. Clustered Versus Dispersed Siting . . . . . . . . . 59

Basic Concepts for Evaluation . . . . . . . . 59

Land Costs . . . . . . . . . . . . . 59

Shared Facilities. . . . . . . . . . 61

Facility-Specific Effects of Cluster Siting . . . . 61

Industrial Coordination. . . . . . . . . . 65

Additional Siting Trade-Offs . . . . . . . . 65 
LIST OF TABLES

PAGE

L. Facilities to be Consldered . . . . . . . . . 5

2. Artificial Island Construction Cost Estimates . . - . . . 25

3. Comparison of Offshore Deepwater Port Facilities . . . . - 31

4. Comparison of Basic Cost Estimates and Their Attributes for Oushore and Offshore Nuclear Power Plants . . . . 35

5. Total Costs of 2,300 Me Nuclear Power Stations Onshore and Offshore . . . . . . . . . • . . • . . 36

6. Capital Costs of 1,150 MNe Nuclear Power Plant Onshore and offshore . . . . . . . . . . . . . 37

7. Comparison of Capital Costs for Onshore and Offshore Nuclear Power Plants . . . . . . . . . . . . . . . 41

8. Comparison of Total Costs for Onshore and of fshore Nuclear

Power Plants - 2,300 Mwe . . . . . . . . . . . 41

9. Comparison of Basic Cost Elements and Their Attributes for Onshore and of fshore Deepwater Ports . . . . . . 45

10. Environmental and Safety Factors for Deepwater Ports . . . 47

11. Savings Resulting From an East Coast US Superport • • • . 48

12. Equivalent Annual Costs of Deepwater Ports Serving the East Coast Market . . . . . . . . . . . . 50

13. Comparison of Basic Cost Elements and Their Attributes for Onshore and offshore Refineries. . . . . . . . 53

14. Recent $0 i 1$ Refinery Proposals for New England . . . . . . 56

15. Onshore-Offshore 011 Rifinery Cost Differences . - • • - 57

16. Siting Criteria for Island Complex - • • • • • • • . 66 


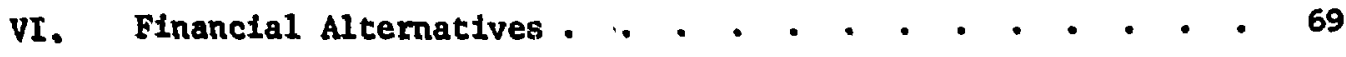

Totally Private Financing - • . . • • . • . 69

Totally Public Financing - • • • • • • • . . 70

Jolnt Private and Public Financing. . . . . . . . 71

vII. Conclusions . . . . . . . . . . . . . . . . 73 
1. Research Approach - . . . . . . . . - . . . . . 6

2. Poider Method of Artificial Island Construction . . . . . . 12

3. Beach Type Sand-Fill Island With Groyne Protection . . . - . 13

4. Land Fill Artificial Island With Sea Defense Wall . . . . . 13

5. Alternative Sea Defense Walls . • • . . • • • • . . . 15

6. Expansion Potential of An Island of 50 Hectares to Approximately 300 Hectares . . . . . . . . . . . . . . 17

7. Proposed Layout for Bolsa Island Project . . : . . . . , 18

8. Proposed Layout for an Industrial/Port Island . - . • . - 20

9. Comparison of Construction Costs Plus Capitalized Maintenance - 22

Costs of Various Sea Defense Systems Per Unit of Length • 22

10. Unit Cost vs Height of Ialand Surface Above Seabed for Three

Typical Islands . . . . . . . . . . . . . . . 23

11. Single Buoy Mooring Factlity - . . - . . . . . . . . 27

12. Single Point Mooring Pler . . . . . . . . . . . . . 29

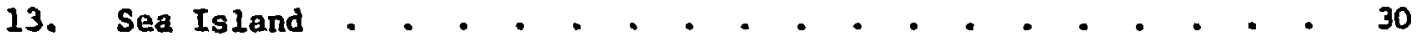

14. Artificlal Island. . . . . . . . . . . . . . . . 30

15. Comparative Cost of Four Alternative U.S. Deepwater Ports

W1th No Environmental Safeguards. . . . . . . . . . 51

16. General Relationships Between $C_{1}, C_{2}, C$ and $A+{ }^{-} \cdot e^{-} \cdot-62$

17. Cost/Area As a Function of Area . . . . . . . . . . . 63

18. Construction Cost Related to the Area of $t$ : Island and Depth $\cdot 63$

19. Relative Comparison of Factors Influenced by Cluster and

Discrete Siting . . . . . . . . . . . . . 68 


\section{Chapter I}

\section{INTRODUCTION}

Ene:gy facilities of varlous types will be needed to meet the energy objectives of the United States, and for a number of reasons, of fshore sites appear to be attractlve. These reasons include:

- The removal from crowded onshore and coastal land areas of potentially hazardous activities such as LNG handling and storage, and nuclear reactor operation;

- The maintenance of the environmental and aesthetic features of onshore and coastal land regions, which make such regions suitable for recreation, conservation and ecosystem protection;

- The avoidance of conflicts between energy uses and other actual and potential uses of the onahore and coastal land reglong, such as wetland protection and shellfishing;

- The proximity of offshore sites to both energy markets and to the energy resource to be exploited offshore $(e .8 ., 011$ and gas), which resourses are to be subjected to a sequence of activities ranging from exploration, drilling, transport and storage;

- The increasing technical and economic feasibility of siting, constructing and operating offshore faciljties, arising in part from the above considerations and in part from independent developments in marine technology such as dredge mining and offshore construction.

Numerous types of fossil and nuclear energy facilities have been proposed for the offshore regions. These include floating island nuclear power plants with breakwater, oil buoys and other deepwater port facilities for very large oil tankers, various drilling rigs and pipelines, fuel processing and waste management facilities; and the co-location of energy intensive facilities offshore has also been proposed.

A rational and compelling approach would involve the clustering of such offshore facilities on artificial islands and structures, which could be sited to meet industrial and other regional demand and supply condicions.

The cluster approach would involve economic tradeoffs for the proprietors of each facility (1.e., perhaps somewhat greater disiances of the facility from markets or resources than would be most profitable if the facility would not be clustered). Further, some facilities could not be clustered (e.g., oil 
exploration and drilling riga). But developing an lolend-based cluster approach for most facilitles, particularly for fuel storage and processing and for energy generation, could ensure more efficlent siting and construction of the facilities, and way enable better management of the pollution and safety risks, transporting, and other ancillary aspects of the facilities. The cluster approach may also ensure that the Inevitable encroachments of such tacilities on coastal and offshore reglons sultable for fishing, tourism, environmental amenities, and other non-energy uses would be minimized.

Such artificlal islands might therefore relleve crowded coastal reglons of the real or Imagined risks attending new energy facilities, such as explosions and other accidents, since the possible occurence of such events would be confined to the artificial 1slands and their environs. The occurence of these risks is kept low in probability by regulatory programs. Nevertheless the magnitude of potential harm to crowded coastal reglons from, for example, an accident at an LNG facility sized onshore appears enormous - particularly if the facility adjoins densely populated residential and tourism regions. By siting such energy facilities offshore, local and state conmunities may come to enjoy the benefits without worrying about some of the potential social costs. 
Chapter II

METHOD FOR ASSESSING ECONOMIC FEASIBILITY

In considering offshore development opportunities the involvement and active participation in planning and decision making of energy developers of the private and public sector, of environmentalists and other public Interest groups, and of economic interests and regulations must be structured to insure that energy problem-solving is both socially responsive and rational.

Obviously, such analyses call for reglonal approaches - in part because of the nature of an energy problem and its relationship to the characteristics of a specific region of the United States; in part because of the magnitude of the social and environmental implications of possible solutions; in part because of the human and fiscal resources required to conduct such analyses rigorously and coherently; and in part because offshore siting of energy facilities is an innovation in the regional scale of energy systems. (1)

The facility development alternatives to be faced by a "regional assessment team" will certainly include the following:

1. onshore facilities separately-sited (the onshore dispersed alternative);

2. onshore facilities clustered in a power park or other complex (the onshore-clustered alternative);

3. offshore facilities separately-sited (the offshore dispersed alternative);

4. offshore facilities clustered on an artificial island of some type (the offshore-clustered alternative);

5. some combination of the foregoing.

In addition, the offshore-clustered alternative involves consideration of three basic island alternatives: an existing natural island, a floating or platform island, or an artificial (land-fill) island. Because this study focuses on the offshore-clustered alternative sited on an artificial island the method to be presented for assessing the economic feasibility of this alternative necessarily involves consideration of, and comparison with, the results of assessing the other alternatives. 


\section{An Ideal Assessment Method}

To accomplish the goal of evaluating the economic feasibility of the offshore-clustered, artificial island alternative in the context of other alternatives, a six-step analytical method has been developed as follows:

1. Selection of priority types of energy facilities technically feasible for offshore siting to meet regional needs;

2. Determination of general siting criteria, site-specific elements of the construction process, and the costs and benefits associated with site-specific elements for each selected type of facility for both of fahore and onshore site alternatives;

3. Identification and evaluation of the further costs and benefits for each selected type of facility being clustered at a site suitable for multiple facilities, for both onshore and offshore cases: (e.g. further costs and benefits such as those arising from cost-sharing and use allocations for common port and communications facilities, more or less stringent thermal discharge limitations, etc.)

4. Consideration of general siting criteria and determination of associated costs and benefits for both on and of fshore cases for the total multiple-facility complex and subsequent allocation of such total facility costs and benefits among the proprietors of each of the clustered facilities. This should essentially verify the results of step 3 above, and enable a tentative cholce between an onshore and of fshore complex.

5. Determiniation of land acquisition and preparation costs for the total multiple facility complex: a) offshore case determination of costs of alternative Island types; the land-fill 1sland, floating island, natural island alternatives; b) onshore case. This should enable a final choice between onshore and specific offshore alternatives.

6. Consideration and assessment of financing alternatives for the total multiple facility complex - offshore case. 
In order to demonstrate this analytical method, a brief hypothetical example, posed as a series of decision questions, is presented. The implementation of the sequence of decisions is shown in Figure 1.

Scenario: A regional energy planning group is constituted and assigned to develop a coherent energy plan to meet the future needs of region I which Includes the northeast coast of the United States. It has developed growth, energy consumption and conservation projections in which it is fairly confident, and now wants to evaluate possible facilitysiting alternatives to meet these energy needs. The group decides to proceed using the methodology described.

Selection of Priority Facilities: The planning group is first faced with deciding which facilities should be given prioity consideration. Table 1 liats possible alternatives, each to be considered for both onshore or offshore siting, and subsequently to be considered for clustering.

TABLE 1

Facilities to be Considered

a) Fuel Processing and Storage Facilities

011 Refinery and Storage

Liquefied Natural Gas (LNG) Storage Terminal

b) Transportation Facilities

Deep Sea Port

Pipelines

c) Energy Generation Facilities

Nuclear Power Plant and Transmission Lines

Fossil Fuel Power Plant and Transmission Lines

d) Auxiliary Facilities

Waste Management

Employee Housing and Amenities

Ship Repair

Facility Maintenance and Repair 


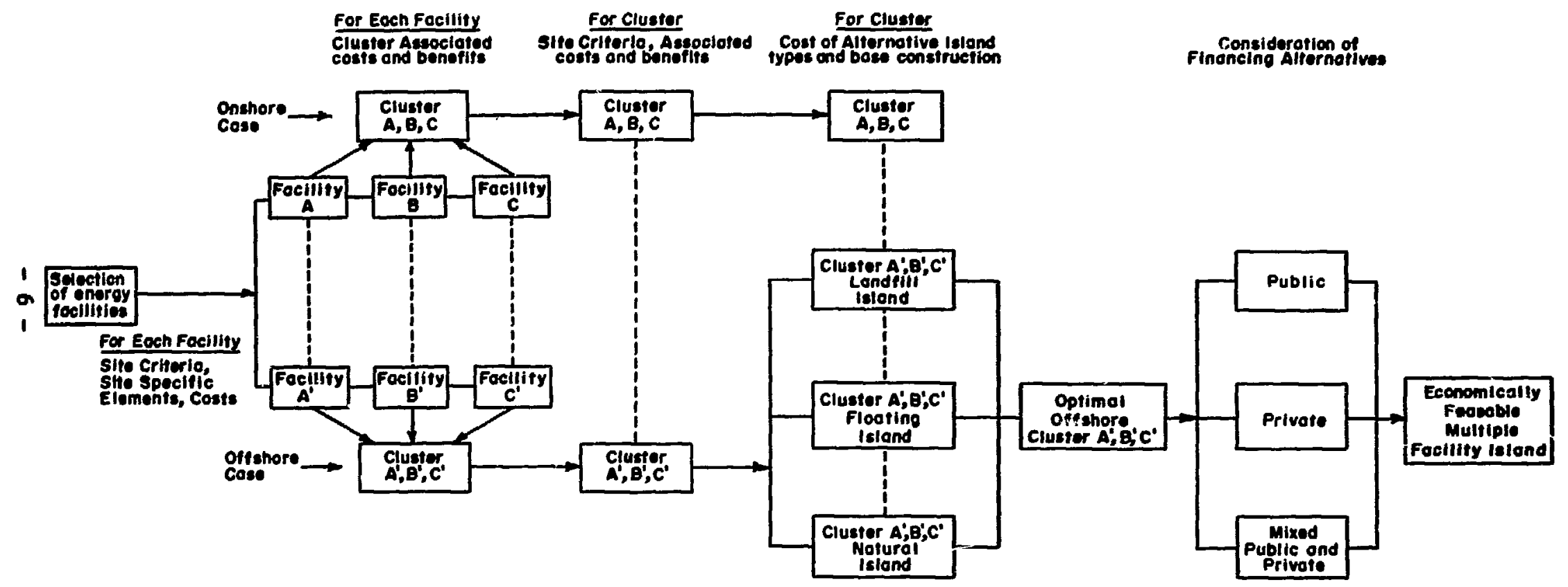

Figure 1. Research approach. 
Decision Question I1: What facilities will be necessary to satisfy present and future regional energy needs?

Hypothetical Decision \#1: Facility $A$ or $A^{\prime}$ - nuclear power plant

$B$ or $B^{\prime}$ - deepwater port

$C$ or $C^{\prime}$ - oil refinery

The letters correspond to those used in Figure 1, the prime referring to the offshore facility.

Onshore-Offshore Comparison For Each Facility

Once the types of factlities have been chosen, the next step is to determine the comparative feastbility of siting each facility at its own site onshore and offshore. To accomplish this, a comparison of the offshore facility to its onshore counterpart would be made (i.e. facility A would be compared with facillty $A^{\prime}$, similarly $B^{\prime}$ to $B^{\prime}$, and $C^{\prime}$ to $C^{\prime}$ ). In order to make this comparison, it is necessary to identify the general siting criteria for each facility, and the site specific cost elements for the design, construction and operation of each facility. These site-related cost factors can thereupon be used to make a comparison of the costs associated with an onshore versus an offshore facility. Because of the highly site specific characteristics of the associated costs, and the usual unstable economic conditions for constructing energy facilities, it will not be possible to come up with precise quantitative comparisons, nor is this essential at this point. What is most essential is to determine the comparative feasibility of siting each of the priority facilities separately onshore and offshore, for even if facjlity $A^{\prime}$ (offshore) does prove to be more "costly" (using "costly" in a very loose sense to reflect subjective judgment as well as actual cost determinations) than facility A (onshore), subsequent determination of the economies of scale and other benefits of the cluster concept may reduce these cost differences, even to the point of ultimately making the offshore facility more costeffective provided it is clustered.

Decision Question 非: Which of the priority facilities can be considered economically feasible for onshore location, and which for offshore location, at their own sites? 
Hypothetical Decision \#2: onshore: A - nuclear power plant

C - oil refinery

offshore: $A^{\prime}-$ nuclear power plant

$B^{\prime}$ - deepwater port

C'- oil refinery

The onshore deepwater part has been eliminated as a feasible alternative. Comparison of Cluster and Dispersed Siting

Once it has been determined which of the various facilities can possibly be located onshore or offshore, it is then necessary to evaluate the costs and benefits associated with a possible cluster location, offshore and onshore. The number of cluster combinations depends on the number of facilities under consideration and can include all onshore facilities, all offshore facilities or varlous subsets. The actual number of cluster possibilities that would be investigated w11l most probably be limited by the planning group's resources of time, money and manpower.

The cluster versus dispersed siting cases can then be comparative1y assessed, by identifying those factors which contribute to the economic benefits of a cluster (e.g. economies of scale, sharing of common facilities): consideration of such potential benefits should include the estimated costs of the environmental and other possible effects arising from clustering (e.g. synergistic environmental effects, safety hazards).

Note that if a dispersed approach, either onshore or offshore, proves more feasible than the clustered approach the analytical process as outlined here is at an end, except for the selection of the dispersed sites tor these facilities.

Decision Question \#3: Is a cluster of energy facilities at a single location, on or offshore, or dispersed facilities more cost-effective?

Hypothetical Decision \#3: Clusters: (A', B', $C^{\prime}$ ) offshore

$(A, C)$ onshore and (B) offshore at a separate site.

Both determined to be more feasible than dispersed siting, or other cluster configurations. 


\section{Cluster Site Selection}

The decision to proceed with a cluster of energy facilities, whether on or offshore, next necessitates a consideration of general siting criteria for the entire complex. Because of the multiplicity of factlities being dealt with, cluster locations which are ideal for each facility probably cannot be realized, and various trade-offs will appear and minst be evaluated to select optimal cluster sites, for both onshore and offshore complexes. This is a relatively straightforward site evaluation and costing task compounded in difficulty by the multiplicity of facilities involved.

Decision Question \#4: Where should such energy complexes be located? Hypothetical Decision \#4: offshore site 1 ' for all three facilities; onshore site 1 for two facilities, with separate offshore site for deepwater port.

\section{Choice of an Optimum Cluster Site}

In contrast to the single onshore cluster site (with separate offshore site for the deepwater port), the single offshore site must then be treated as three possible alternative configurations: a natural island, a land-fill island and a floating island. The cost of the site itself and the site preparation for each must next be estimated and compared. This leads to selection of a specific energy facility cluster at a specific site in a specific configuration.

Decision Question \#5: What is the optimum multi-purpose energy cluster site and configuration?

Hypothetical Decision \#5: Land-fill island at Site 1' with facilities $A^{\prime}, B^{\prime}, C^{\prime}$.

Choice of Financing Alternative

No matter how feasible the first five steps are determined to be, the concept cannot be applied unless an adequate means of financing its realization can be provided. Three basic a!ternatives exist for exploration: 
public financing, private financing, or a $\mathrm{mix}$ of public and private suppoxt. Each alternative can be subdivided Into several variations: e.g. public financing may come from federal, state, or local sources and procedures. Decision Question *6: How can the offshore land f111 lsland complex be funded?

Hypothetical Decision \#6: Public financing with long-term leasing by state governments on the basts of a sharing formula based on various factors such as population served, additional energy to be supplied to private industries and utilities; etc.

\section{Application of Method}

The above described methodology for assessing economic feasibility is an "Ideal" approach, and undoubtedly some adjustments have to be made in any actual case study. The discrete step-by-step approach should be useful In coming to grips with a very complex problen such as the feasibility of an artificial island; however in reality it is not always possible to take a series of completely 1solated steps. The interrrelationships and dependencles of all aspects of such a problem are simply too great. Nor does one necessarlly want to segment a specific problem and lose perspective as to its totality. In actuality, the planning and decision-making processes that would ensue in the region would be highly iterative, rather than occur as a flow-through process. In addition, time and resource constraints have a limiting effect on the scope of the problem and the rigor with which it is addressed. 
Chapter III

OFFSHORE STRUCTURES FOR ENERGY FACILITIES

Artificial Islands

The techniques of creating islands have evolved primarily from the activities of the Dutch at reclaiming land from the sea and otherwise protecting their coast over several centuries. Protection of the coastline, extension of the shore, and now the creation of artificial islands involve essentially similar techniques and equipment, and the Dutch and neighboring European nations have developed considerable experience in their application. There are two basic types or construction methods avallable for the creation of an artificial island: the polder method and the land fill method. The basic difference is that the former results in an island whose surface is largely below the mean water level, at least initially, while the latter results in a more conventional or nacural type island with its land surface above that of the sea.

The Polder Method

The basic polder method of construction is shown schematically in Figure 2. The first stage of the construction process is the development of relatively impermeable dikes around the area which is to be reclaimed. This is followed by programmed drainage of the enclosed water and eventually results in the polder, the new land which was once the submerged seabed at the site. Continuous year-round drainage is required to remove water which seeps through the dikes or enclosed seabed. This need for maintenance, for continuous artificial drainage, is the critical, limiting factor in determining whether or not a polder island will be economically feasible for the anticipated uses.

Land Fill Methods

There are numerous types of land-f1ll methods, but all essentially involve the deposition of large amounts of sand and gravel in a particular area to rafse the resulting island surface above that of the sea. The various land-fill methods differ mainly in the way this fill material is maintained in place, and range from unprotected beach islands to islands protected by caisson containment structures. 


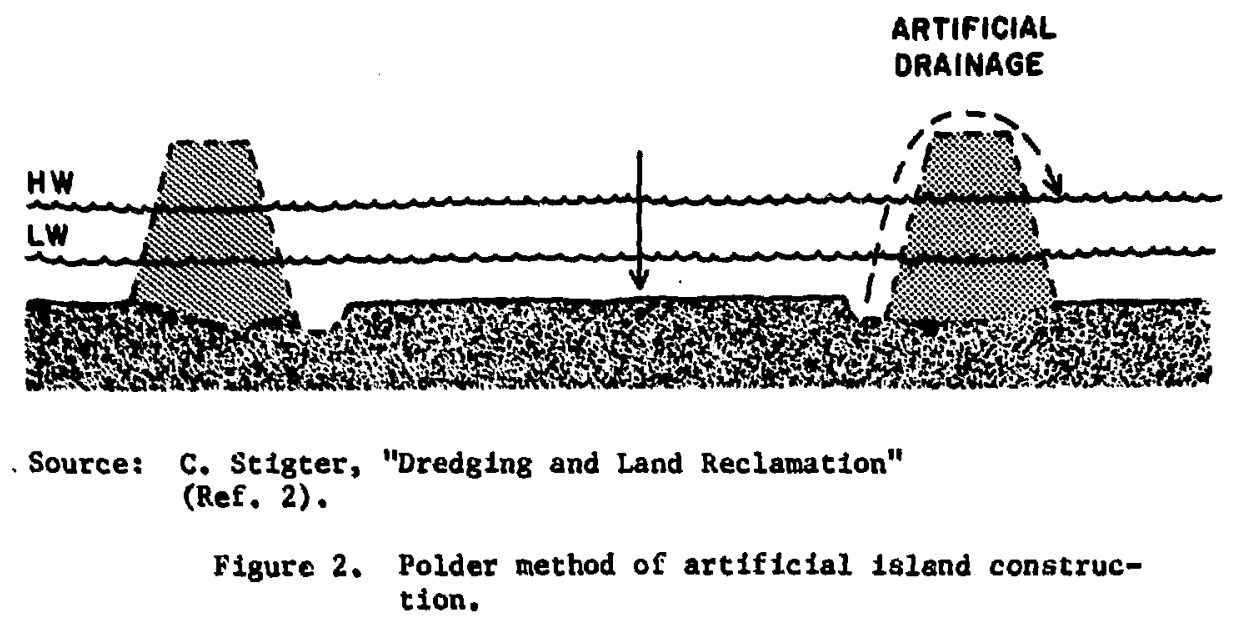

Beach Sea Island

Beach sea islands are constructed by placement of sand and gravel fill to form relatively flat islands with slightly sloping coastlines rising above the water surfaces. Exposure to breaking waves or littoral currents can cause severe erosion problems for this type of isiand, and therefore some method of erosion prevention is generally required. Groynes made of either rubble mounds or rows of piles along the island perimeter can be constructed for this purpose.

Although this type of land fill island is premised on no need for an extensive sea defense wall, greater amounts of fill material to offset anticipated erosion and constant replenishment of fill may be required. For such reasons, this type of island construction is most applicable to sites not exposed to severe wave attack or other significant causes of erosion. Figure 3 shows a profile of such an island. (3) 


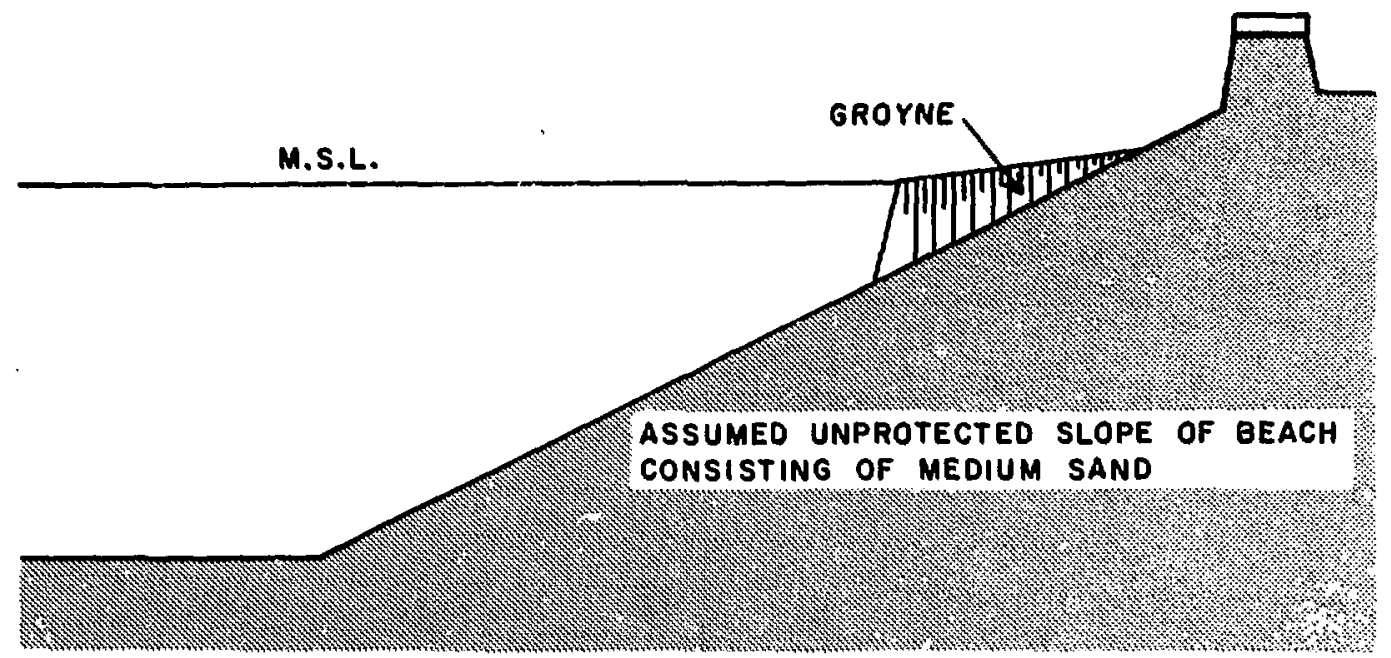
Source: Bos Kalis Westminster Dredging Group "Sea Island
Project."

Figure 3. Beach type sand-fill 1sland with groyne protection.

DOUBLE LAYER OF CONCRETE BLOCKS

M.S.L.

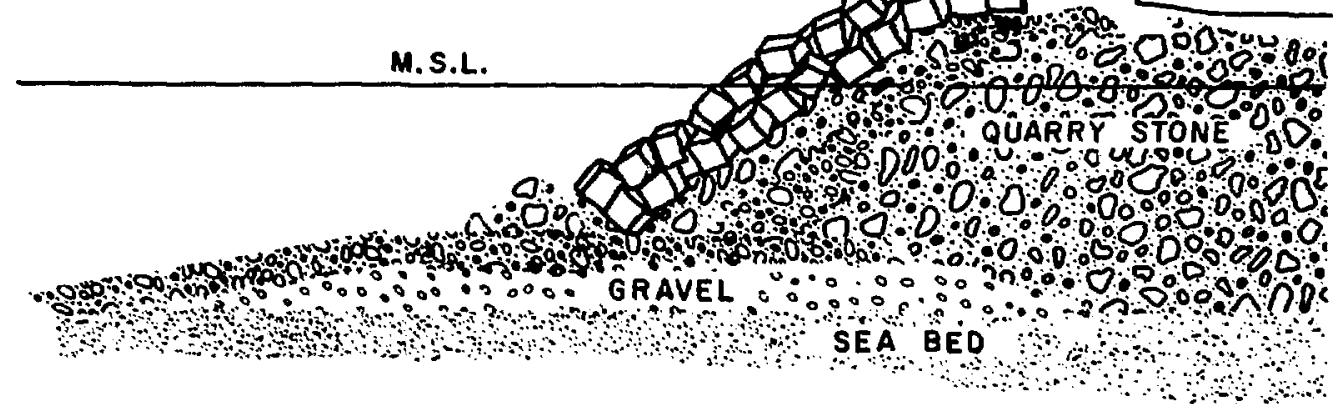

Source: Bos Kalis Westminster Dredging Group, "Sea

Island Project" (Ref. 3).

Figure 4. Sand-fill artificial 1sland with sea defense wall. 
Land F111 Island With Sea Defense Hull

In areas where wave activity or currents make the cost of maintenance and erosion replenishment economically prohibitive, or where more protection Is desired for structures to be sited on the 1sland, an extensive sea defense wall may be reçilred. Figure 4 shows such a structure composed of gravel, quarry stones and concrete blocks. In regions where quarry stone is not readily available, or if greater protection is warranted, the stone and concrete blocks may be replaced by interlccking dolosse, which are large concrete structures in tile shape of childrens' jacks. Islands provided with such defense structures can be built with steeper slopes, therefore requiring slightly less fill and malstenance; however the additional cost of these defense walls precludes any savings in construction costs.

Dike and Fill Method

The dike and fill method of constructing artificlal lslands is similar to the polder method shown in Figure 2. The difference is that rather than draining the area behind the dike, this area is filled with sand and gravel generally dredged from nearby sites, to create an 1sland surface entirely above the sea. The dikes can be provided with rubble mound or other sea defenses, as described above, for greater protection. Variations

The specific design of artificial islands will depend on a number of factors including water depth, atmospheric and oceanographic conditions, the availability of $\mathrm{f} i 1 \mathrm{l}$, and the uses for which the island is intended. Variations in the two basic types of offshore islands are dependent on the specific laynut of the island and the type of perimeter or sea-defense wall used to protect the Island from erosion. These include not only the grayne and dolosse walls but also prefabricated concrete cissons, which are towed into position, sunk in an interlocking arrangement and then filled with sand and gravel; sheet piles which are driven into place and then filled with dredged material; and sheet pile cells or cofferdams which are driven into place and then backed and filled with dredged material or rocks. These alternatives are shown in Figure 5 . Recent Artificial Island Projects and Proposals

The most ambitious effort for the construction of artificial islands has been proposed for the North Sea by a group of Dutch industrial interests now awaiting authorization to proceed by the Dutch government. (5) The 


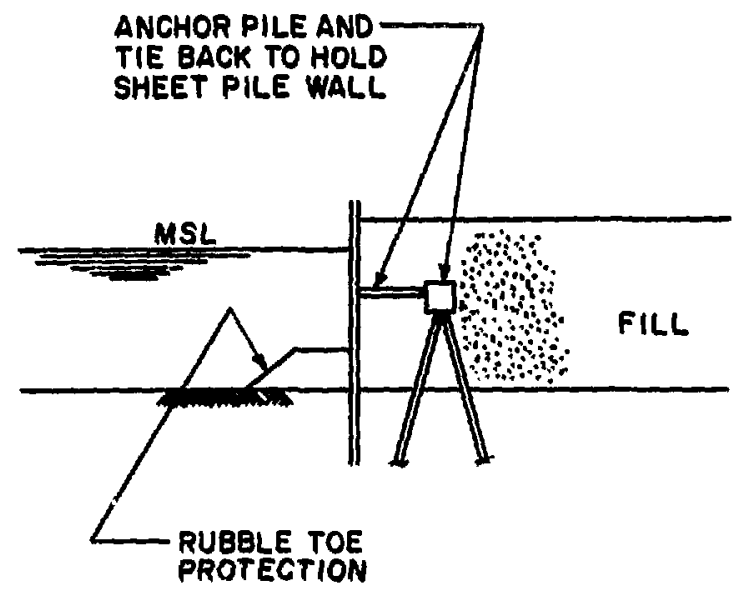

SHEETPILE METHOD*
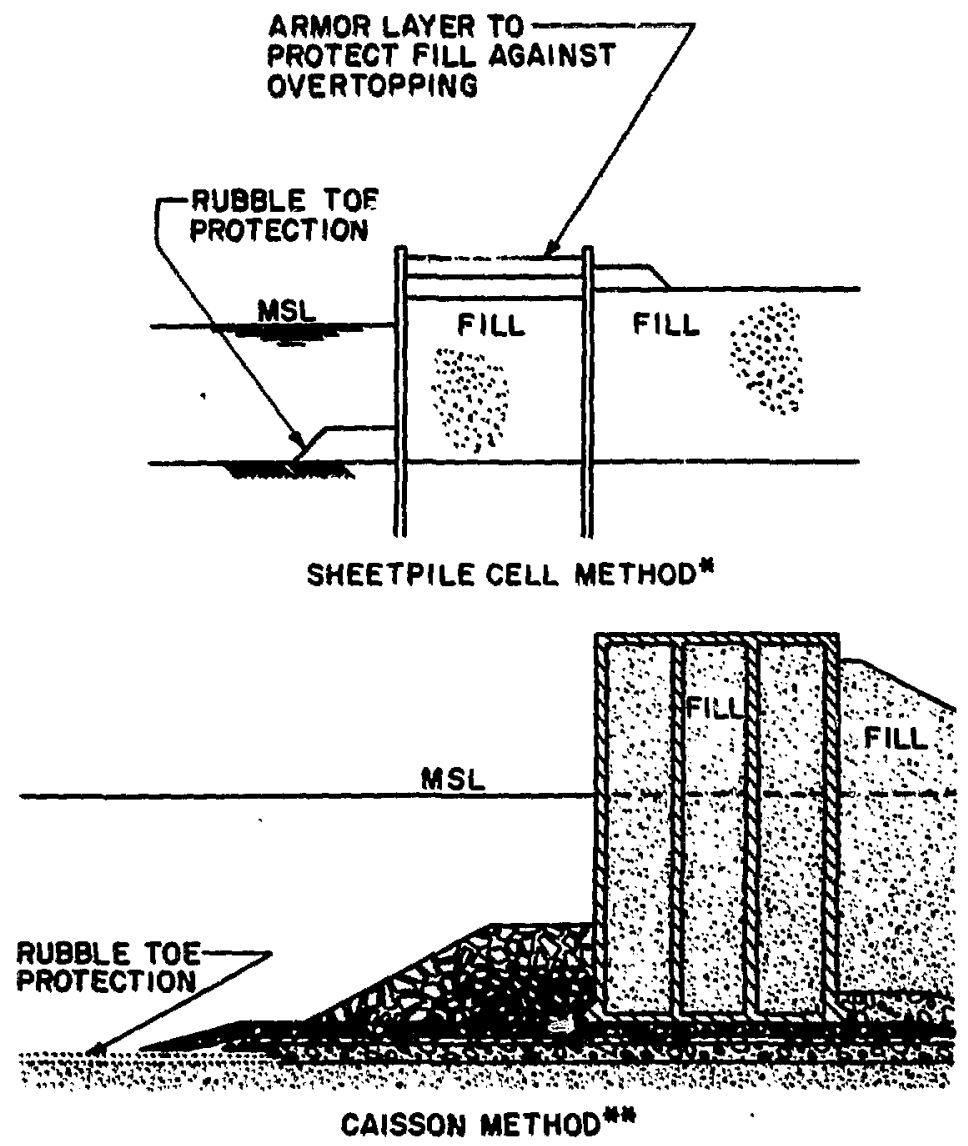

\footnotetext{
*Reference: J. Bonaaia "An Evaluation of Mult1-Purpose of fahore Industrial/Port Islands for the Atlantic and Gulf Coasts-C1vil Engineering Con:atderations" (Ref. 4).

* Reference: Bos Kal1s Weatminster Dredging Group, "Sea Ieland Project" (Ref. 3).

Figure 5. Alternative sea defense walls.
} 
proposal grew out of the conflict between the objectives of continued industrlal development and a healthy environment in the densely populated Dutch coast flanking the North Sea, and has been given Impetus by the avaisability of skilled personnel and sophisticated tecnnologies.

The 1sland designs proposed are those suttable for several types of facilities with the option of extension to larger islands as needed for additional facilities. The proposed project would start with a relatively small island (125 acres), which would serve several facilities and would also act as a construction base for further expansion of the island as further facilities are needed.

The second phase of construction would entail expansion of the original island to 750 acres to be used for other specialized industries and either an oil cerminal or a repair harbor for damaged ships. Further expansion to 2500 and 3000 acres would accomodate additional industrial activity or possible transportation facilities such as an airport. Figure 6 depicts this scheme for progressive expansion.

Although the island is still in the proposal stage, the consortium of developers are optimistic about its future. Strong united support from the industrial developers, a notable lack of opposition from the Dutch government, and the support of environmentalists such as Jacques Cousteau, (6) indicate that this optimism is well-founded and that such islands may soon be built in the North Sea.

Bolsa Island

In the mid $1960^{\prime} s$, a project jointly sponsored by the Metropolitan Water District of Southern California, the United States Atomic Energy Comission and the Department of Interior and conducted by the Becintel Corporation was launched to study the feasibility of a dual-purpose, nuclear power-desalination plant. (7) The project received considerable atcention and support as a potential panacea for water-starved areas around the world.

The Bechtel study compared various onshore and offshore alternatives for the siting of the facilities. At the time of the original study, the concept of most promise was an offshore artificial island to be located in approximately 30 feet of water and sited 2800 feet of $f$ the California coast near Bolsa Chica State Beach In Orange County. "The Island was designed as a free standing structure... with a usable surface area of 

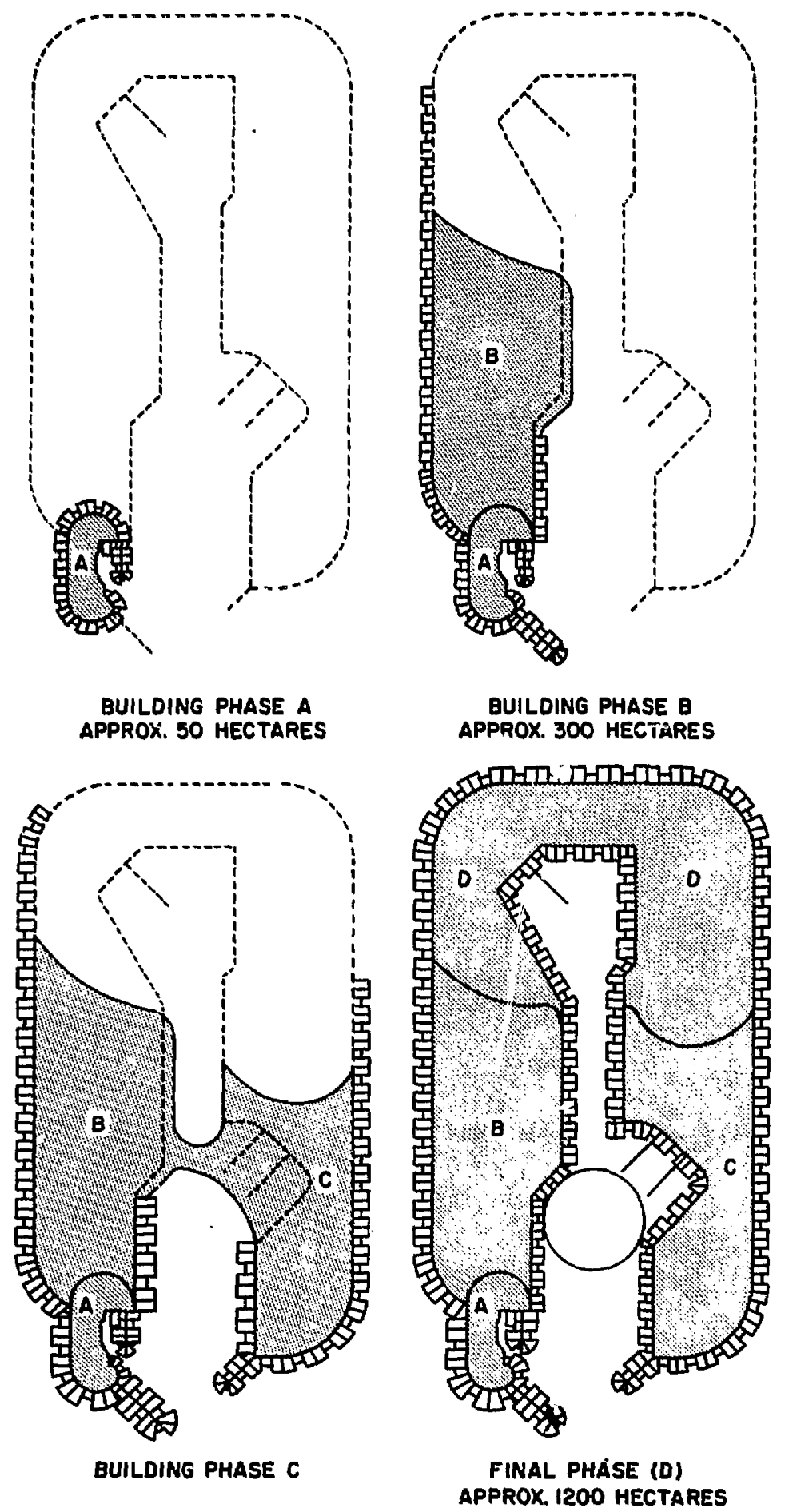

Source: Bos Kal1s Westminster Dredging Group, "Sea Ialand Project" (Ref, 3).

Figure 6. Expansion potential of an 1siand of 50 hectares to approximately 300 hectares. 
approximately 36 acres,....to be compriand of a quarry rock perimeter wave defense, an Interlor of dredged sand $f 111$, and an open pile-bent causeway....connecting the island to the mainlani." (8) A simplified layout of the proposed island is shown in Figure 7 .

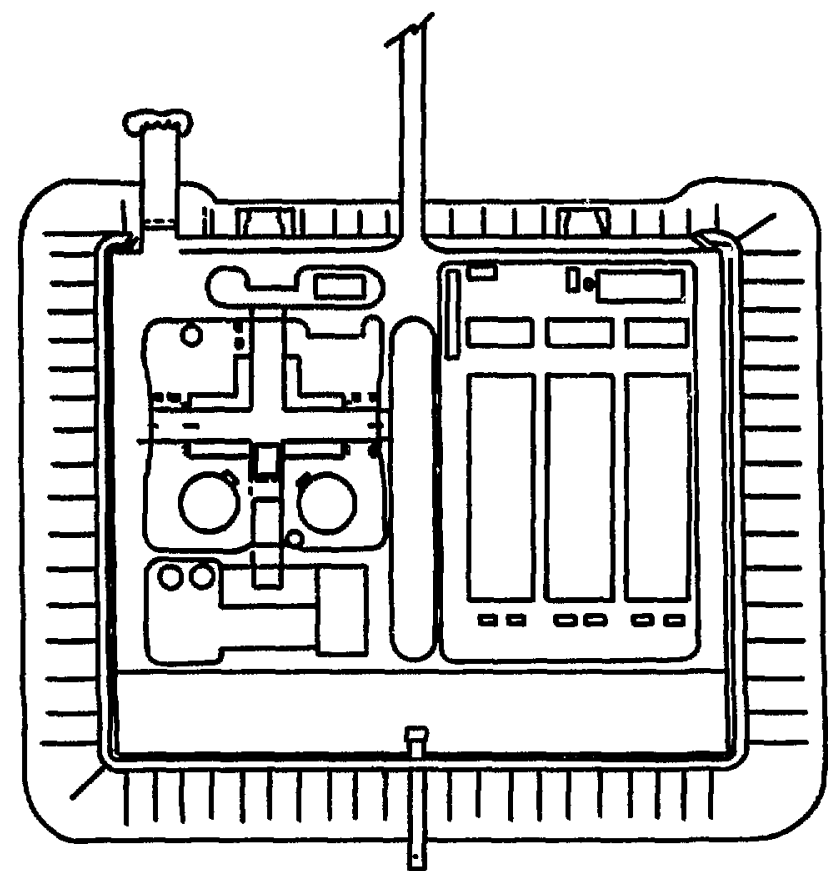

Source: T. Spriggs, "Conceptual Design of a Man-Made Island for a Seawater Deslating and Power Plant" (Ref. 8).

Figure 7. Proposed layout for Bolsa Island profect.

\section{University of Delaware Study}

A study entitled "Mult1-Purpose Offshore Industria1-Port Islands" under the direction of the College of Marine Studies of the University of Delaware is presently nearing completion $(4,9,10,11,12)$. Although tied directly to the Gulf and East coasts of the United States, this project is more hypothetical than those previously described. 
The study is governed by three general siting criteria:

1. a water depth less than 60 feet;

2. outside the 3 mile territorial sea;

3. proximity to market demand, as indicated for example by recent proposals for refineries.

For the Northeastern coast the following areas were chosen as having high potential for island sites: the northern coast of Malne, a portion of Boston Harbor, the sourthern coast of Massachusetts in the vicinity of Martha's Vinayard, Long Island Sound, the central portion of the New Jersey Coast, and the mouth of Delaware Bay. $(9)$

Waste minimizațion criteria were used in the selection of industries to be sited on the 1sland - Industries which could use products or residual materials of other Induatries were chosen for clustering on a particular island site for purposes of the study. One of the island plans arrived at is shown in Figure 8. (4)

\section{Mining and Drilling Islands}

Most of the few islands which have been actually constructed to date are used to facilitate offshore drilling and mining operations. Imperial 011 Ltd. has constructed "an oval-shaped pile of gravel $900 \mathrm{ft}$. across the base along Its long axis and standing only $25 \mathrm{ft}$. high at the center" in the Beaufort Sea for use as a base for its offshore oll drilling. More of the same are planned for the future. In addition "four 10-acre man-made islands were constructed by THUMS (an oil company) off the cuast of Long Beach, California, for the purpose of drilling oil wells in the East Wilmington field. These 1slands were constructed with rock perimeters. The enclosed areas were filled with materlal dredged from the harbor." (14) Finally,"...off the Japanese coast there are already several artificial . . islands of rock and earth construction in about 40 meters of water. providing access to offshore coal mines" by means of shaft mining.

\section{Island Transhipment Terminals}

Artificlal islands are also now being built for use as transhipment terminals. One island built in the Atlantic Ocean, eight miles off the 


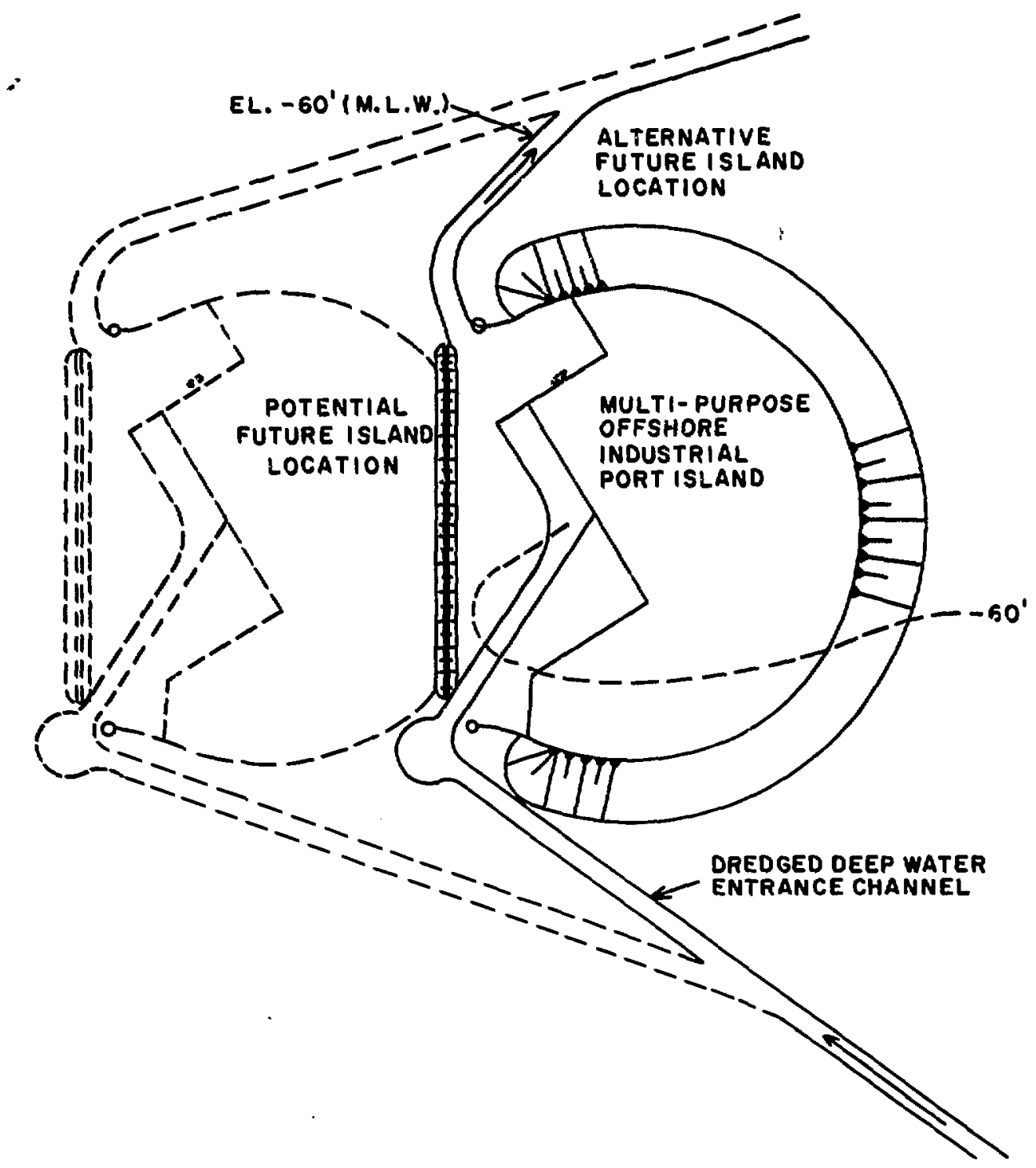

Source: J. Bonasia, "An Evaluation of Mult1-Purpose Offshore Industrial/Port Islands for the Atlantic and Gulf Coasts-Civil Engineering Considerations" (Ref. 4).

Figure 8. Proposed layout for an Industrial/port island. 
coast of Brazll, by the sheet-pile cell method of construction previously described, is intended for use for the transhipment and storage of salt destined for foreign markets. (16)

SImilar terminal 1slands have been proposed for Angola, Macao and Mozambique, respectively for the exporting of timber and phosphates; for handling conventional cargo ships; and for handling deep draft vessels (up to 250,000 tons) carrying phosphates, coal and iron ore.

A major reason for these islands is the need for deeper tiarbors arising from the growing use of larger, deep draft vessels. Deepening of existing channels to facllities on shore is often economically prohibitive, and of fshore islands can relieve this need for extensive dredging. In addition, such lslands are belleved to cause less disturbance to currents along the shore, to wave action on the shore, and to the coastal environment than deepening of channels to existing facilities on shore. Finally, congestion of shipping and the frequency of ship grounding and other accidents are greatly reduced. (17) As mure large ships are used to transport goods, deeper harbors and ports will be needed, and artificial island development may well proceed on this bas is along.

$\underline{\text { Recreational Islands }}$

A final use for which artificial islands have been considered is for recreational purposes. The increasing demand for coastal recreational activities and the decreasing availabijity of coastal regions make artificial islands an attractive alternative.

One area which has been given considerable attention in this regard is Long Island Sound. The iNew England River Basins Commission has conducted a study which concluded that: "... islands could be constructed using dredged spolls (materials dredged in routine channel and harbor maintenance) and construction waste to meet long-range recreational and public access needs at a cost of $\$ 40,000$ per acre compared to existing land prices as h1gh as $\$ 200,000$ per acre." The first island which may be constructed would be sited in Pelham Bay and development by the Corps of Engineers is tentatively scheduled to begin in 1978. About 
1.5 miles of public beach would be created, including 200 picnic sites and 50 boat slips. (18)

Finally, the use of the artificial island to provide wildife and bird sanctuaries should also be noted. A program to restore Poplar Island in Chesapeake Bay has been proposed for such conservation purposes, and would involve the construction of a durable breakwater with backfilling using baled and encapsulated waste material from municipalities. Besides conserving the island, this method provides a means for disposing of large amounts of municipal refuse, and therefore opens up for consideration other possible functions of artificial islands.

Cost of Artificial Island Construction

Estimates of construction costs for artificial islands vary greatly. Three significant variables in the determination of these costs are the island design, most importantly the type of sea defense necessary; the water depth at the site; and the size of the 1sland. Other key variables would include the availability of fill material, the need for on-shore facilities to service the islands, and costs assoclated with permit processes and pollution control requirements.

The relative effect of the first of these, the type of sea defense, is shown in Figure 9, which indicates that for a given set of conditions

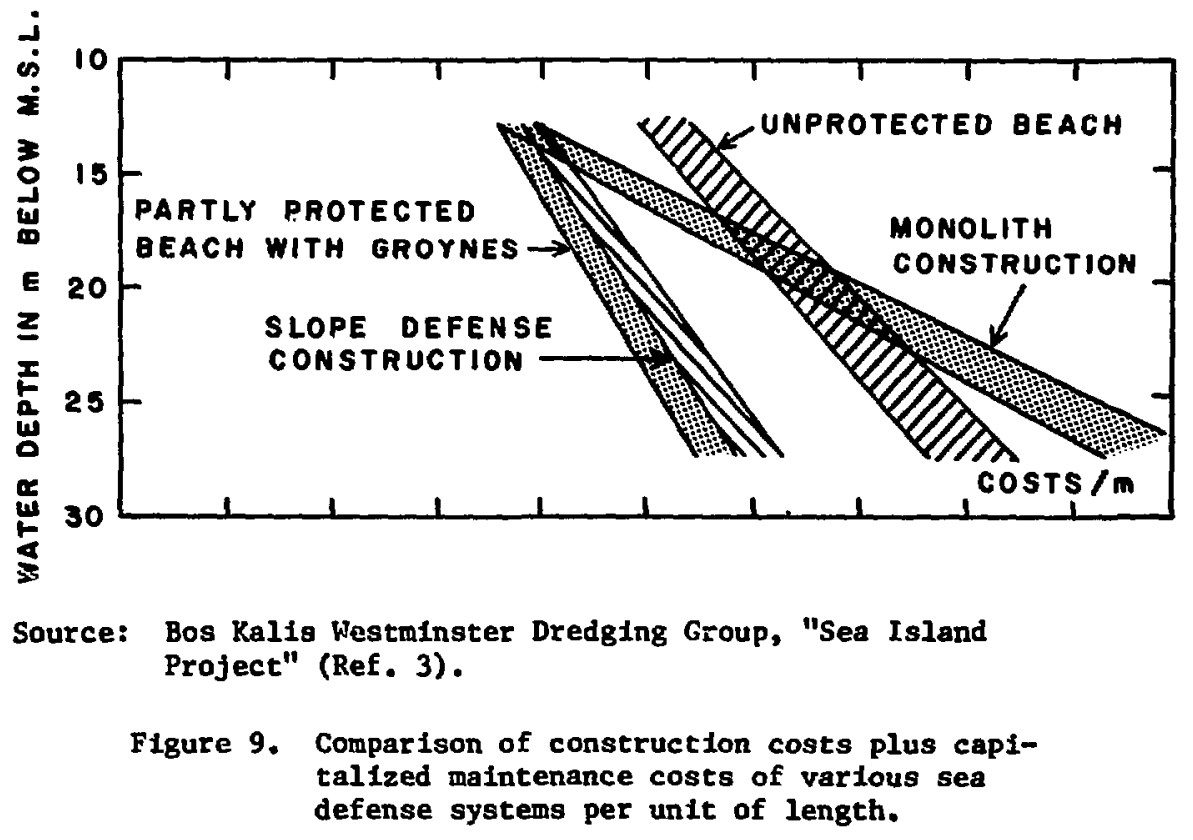


a beach type island protected with groynes is generally the least expensive, followed by a beach type protected with concrete blocks. At shallow depths (20 meters) caissons rank next followed by an unprotected beach type island. At greater depths the unprotected beach type becomes less expensive than the caisson method.

The effect of depth is fairly obvious: as depth increases, the amount of fill that is needed to create a unit of surface area increases, hence the unit costs/area increases. The depth factor is somewhat deceptive, however, since the critical parameter is really the helght of the island surface above the natural seabed at the site. This relationship of unit cost to height of fill for three typical islands is shown in Figure 10.

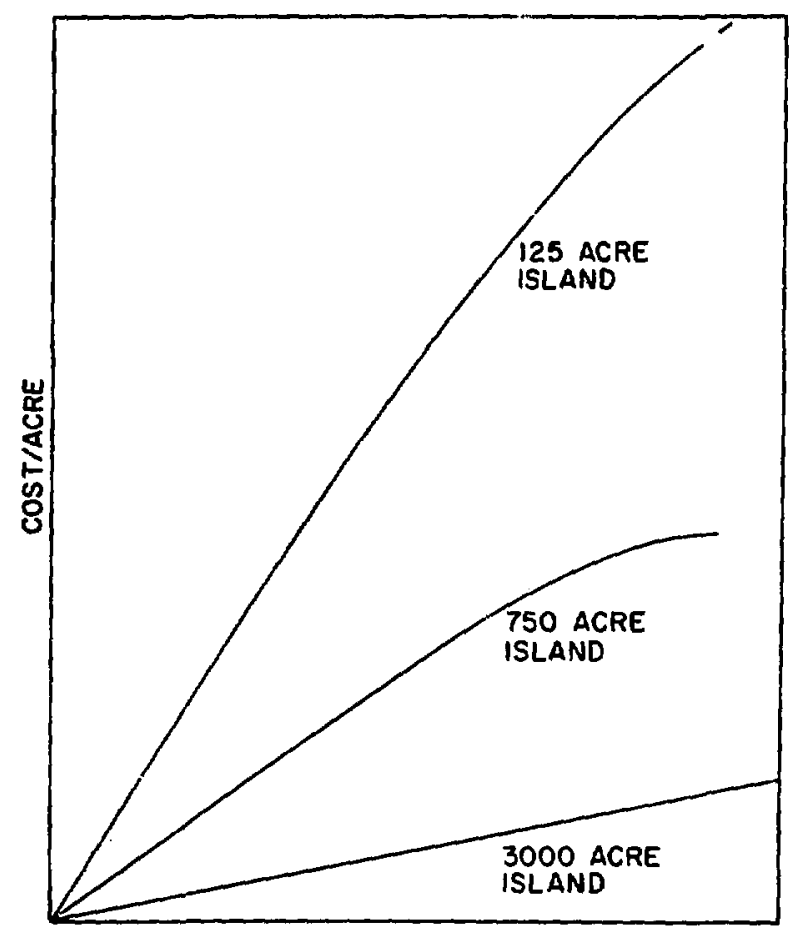

HEIGHT OF ISLAND ABOVE SEABED

Source: Bos Kalis Westminster Dredging Group, "Sea Island Projec:" (Ref. 3).

Figure 10. Unit cost vs. helght of Island surface above seabed for three typical islands. 
Avallable information regarding actual loland costa is shown in Table 2. Th1s data reflects the importance of the three variables discussed above, and serves the purpose of providing a ballpark estimation of artificial island construction costs for use in this study. (20)

\section{Deepwater Ports}

The second type of facility chosen for this study of the economic feasibility of a multi-purpose artificial island is the deepwater port. A substantial portion of the total capacity of the world's tankship fleet is presently composed of so called supertankers or "Very Large Crude Carriers (VLCC)", and this portion has been increasing despite a diminuation In actual need. Supertankers are vessels capable of hauling large amounts (200,000 to 500,000 deadweight tons) of crude oil; they also require a great depth of water ( 60 to 90 feet) in order to operate.

The major function of American deepwater ports would be the transhipment of U.S. offshore or forelgn crude oll coming Into the United States by means of supertankers. The economic advantages of deepwater ports which will be discussed in this paper are of no significance if, once bullt, forelgn importers restrict the inflow, or if U.S. offshore sources are not developed. Before an extensive deepwater port program is initiated (three such Facilities have been proposed) a national

determination of needs for such ports obviously should be made. $(21,22)$ Deepwater Port Alternatives

Onshore - The onshore deepwater port alternative essentially involves the dredging of existing ports in order to facilitate the deep draft requirements of supertankers. Existing ports generally range in depth from 30 to 45 feet, while, as noted above deepwater ports will require up to twice such depths. In addition, such ports will require extensive channel widening and lengthening in many cases to enable VLCC's to maneuver. Supertankers require special berths and large slowdown areas in order to reduce the considerable momentum they develop even at slow docking speeds. Very large turn around areas are also required for the safe passage of these ships, into and out of a harbor. Therefore in addition to the 
TABLE 2

ARTIFICIAL ISLAND CONSTRUCTION COST ESTIMATES

\begin{tabular}{|c|c|c|c|c|}
\hline $\begin{array}{l}\text { Year of } \\
\text { Estimate }\end{array}$ & $\begin{array}{l}\text { Island Type } \\
\text { \& Location }\end{array}$ & $\begin{array}{l}\text { Size } \\
\text { (acres) }\end{array}$ & $\begin{array}{l}\text { Water } \\
\text { Depth (ft) }\end{array}$ & Cost/Acre (\$) \\
\hline 1975 & $\begin{array}{l}\text { Calsson (Gulf } \\
\text { or Eastern U.S. } \\
\text { Coast) }\end{array}$ & 3000 & -60 & 250,000 \\
\hline 1975 & $\begin{array}{l}\text { Caisson (Gult } \\
\text { or Eastern U.S. } \\
\text { Coast) }\end{array}$ & 2000 & -60 & 275,000 \\
\hline 1974 & $\begin{array}{l}\text { Dike \& Fill } \\
\text { (Long Isl. } \\
\text { Sound) }\end{array}$ & $>1000$ & 20 & $\begin{array}{r}60,000 \\
150,000\end{array}$ \\
\hline 1974 & $\begin{array}{l}\text { Dike Fill } \\
\text { (Long IsI. } \\
\text { Sound) }\end{array}$ & $<5$ & -40 & 500,000 \\
\hline 1974 & $\begin{array}{l}\text { Polder (Long } \\
\text { Isl. Sound) }\end{array}$ & $\begin{array}{r}>1000 \\
<5\end{array}$ & $\begin{array}{l}0-10 \\
0-10\end{array}$ & $\begin{array}{r}30,000 \\
100,000\end{array}$ \\
\hline 1968 & $\begin{array}{l}\text { Sand F111; Rock } \\
\text { Revetment } \\
\text { (Calif.Coast) }\end{array}$ & 40 & 27 & 612,000 \\
\hline 1972 & $\begin{array}{l}\text { Sand Fill } \\
\text { Rubble Mound } \\
\text { Sea Defense } \\
\text { (North Sea) }\end{array}$ & 125 & $\begin{array}{l}33 \\
66 \\
98\end{array}$ & $\begin{array}{l}405,000 \\
615,000 \\
779,000\end{array}$ \\
\hline 1972 & $\begin{array}{l}\text { Sand Fill } \\
\text { Rubble Mound } \\
\text { Sea Defense } \\
\text { (North Sea) }\end{array}$ & 750 & $\begin{array}{l}33 \\
66 \\
98\end{array}$ & $\begin{array}{l}178,000 \\
292,000 \\
340,000\end{array}$ \\
\hline 1972 & $\begin{array}{l}\text { Sand Fill } \\
\text { Rubble Mound } \\
\text { Sea Defense } \\
\text { (North Sea) }\end{array}$ & 3000 & $\begin{array}{l}33 \\
66 \\
98\end{array}$ & $\begin{array}{r}48,500 \\
81,000 \\
113,000\end{array}$ \\
\hline
\end{tabular}

Source: References $3,4,20$ 
Increase in depth required if existing onshore ports are to be adapted to the handling of VLCC's, special slowdown and turn-around features must also be incorporated Into harbor modification plans.

\section{Offshore}

The number of possible configurations for an of fshore deepwater terminal are too numerous to be considered in detall here. Basically, a terminal must provide for four functions:

1. berth

2. transhipment from berth to storage

3. tank farm storage

4. transhipment from storage to refinery

An optional fifth function would consist of tanker repair and spill control. Each of these in turn can be broken down into varlous types of facilities. Six general types of deepwater terminals are described in an attempt to show the range of possible configurations.

\section{Single Point Mooring (SPM)}

The single point mooring concept of a deepwater port is shown schematically in Figure 11. It normally cousists of a flat, cylindrical buoy with a vertical axis, held in place with chalns attached to anchors or piles driven into the ocean floor. The oil is discharged from the vessel through flexible hoses which allow for movement of both the buoy and the vessel. The oil is then transferred through another flexible hose to a submarine pipeline, which in turn carries the oil to an onshore tank storage farm. Transhipment from an on-land storage area to a refinery can employ the use of pipelines and various vehicles.

\section{Single Anchor Leg Mooring}

The single anchor leg mooring system is very similar to the SPM, the major difference being that the hose and swivel mechanism is located on the sea bed rather than on a floating buoy.

\section{Conventional Mooring Buoy}

This conventional mooring is a fixed berth system using several buoys to maintain the tanker In a given position during the unloading operation. 


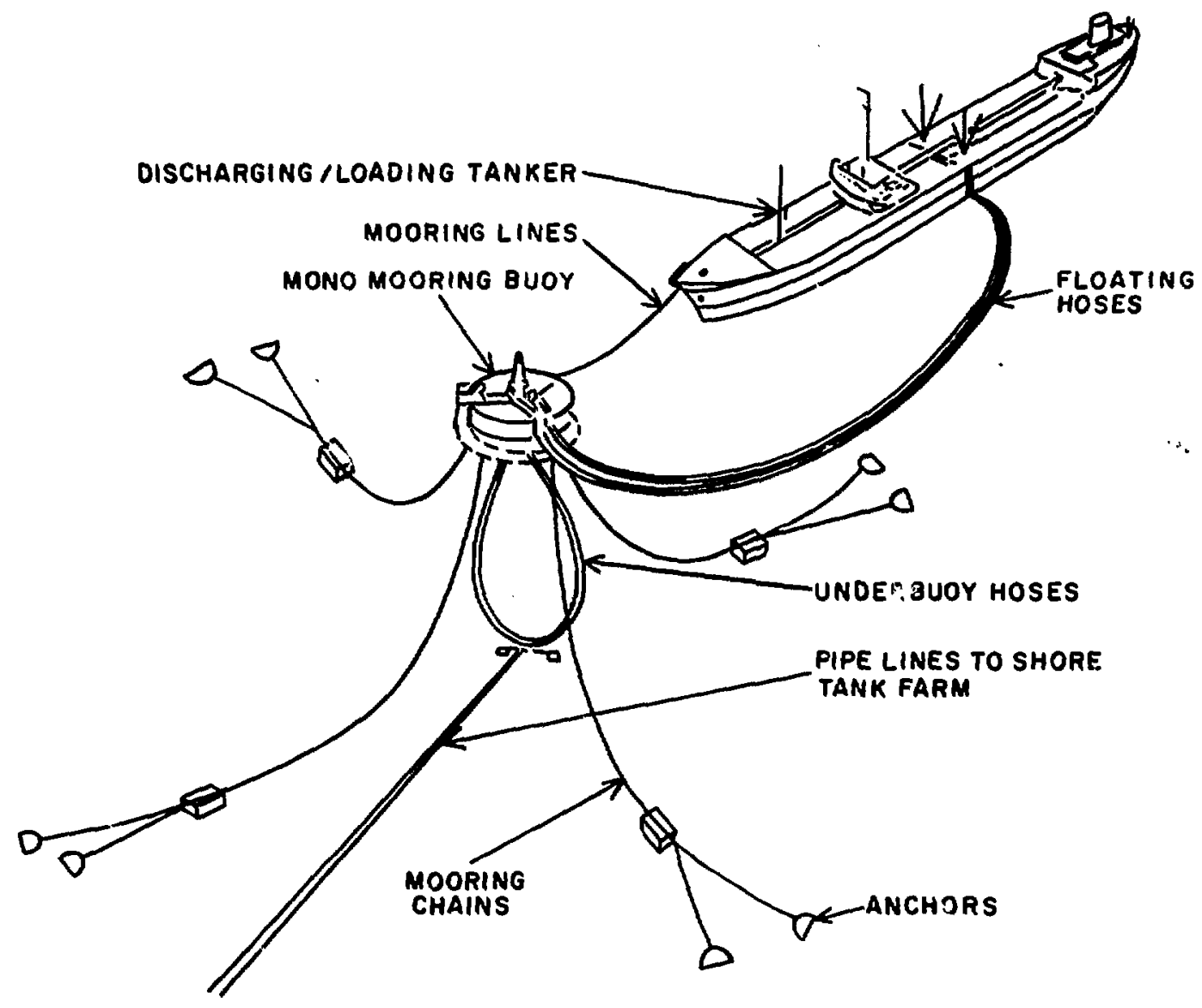

Source: Corps of Engineers, as presented in U.S. Department of Interior, Environmental Impact Statement: Deepwater Portg.

Figure 11. Single buoy mooring facility. 
Once the tanker is at berth, the oil is pumped through flexible hoses connected to a submarine plpeline which leads to an onshore storage facility. Single Point Mooring Pler

This pier-type port facility consists of a rigid tower or pylon fixed to the sea floor, on which is mounted a long semi-submersible floating structure (Figure 12.) The oil is carried by a short hose through the semi-submerstble berth to a submarine pipeline.

\section{Eloating Platform}

The floating-platform type facility designated as a "Sea Island", is shown in Figure 13. The basic differences between this type and those previously described are the fixed berths, and the offshore storage facilities. This type also offers the alternative of transhipment or barges, if this is more economical or otherwise favored over a plpeline configuration.

\section{Artiflcial Island}

The artificial island (Figure 14) differs from the floating platform type in the use of a dike and sand and gravel fill. It offers the additional benefit of allowing other related and non-related activities to be sited and carried out on the island. This concept will be discussed further.

Comparison of Offshore Deepwater Port Alternatives

Many factors will influence the choise of facility for a particular site. Table 3 provides a comparison of the relative capital cost of each type, the sea state in which it is operable, its vulnerability to damage and the subsequent maintenance required, and its oil capacity based on tanker size and flow through capabilities. 


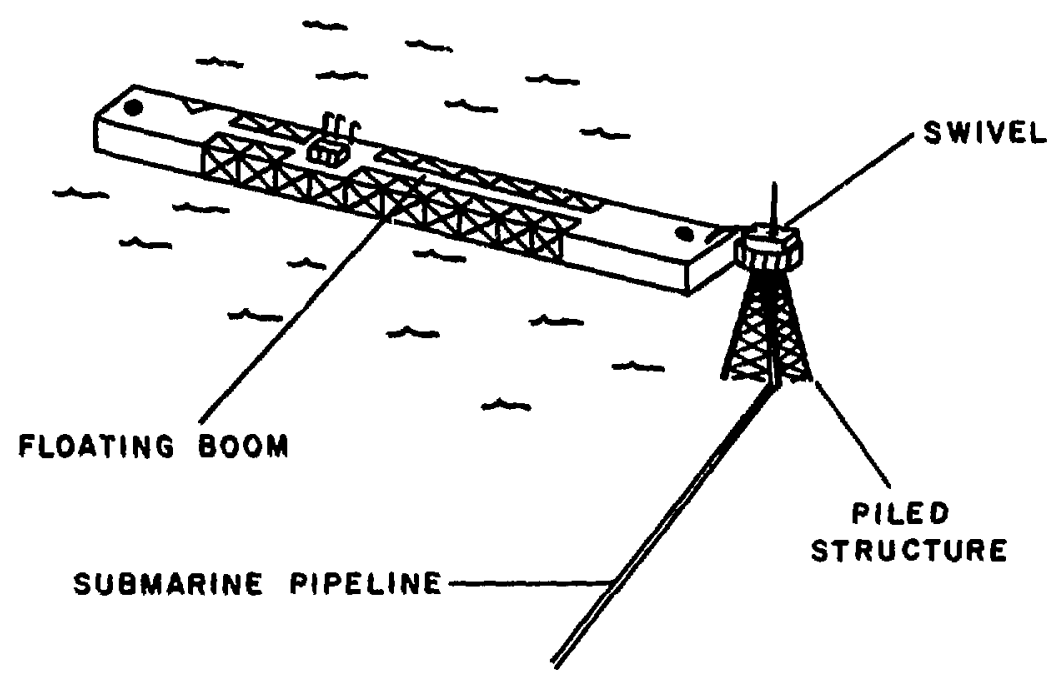

Source: Corps of Engineers, as presented in United States Department of Interfor Environmental Impact Stetement: Deepwater Ports.

Figure 12. Single polnt mooring pier. 


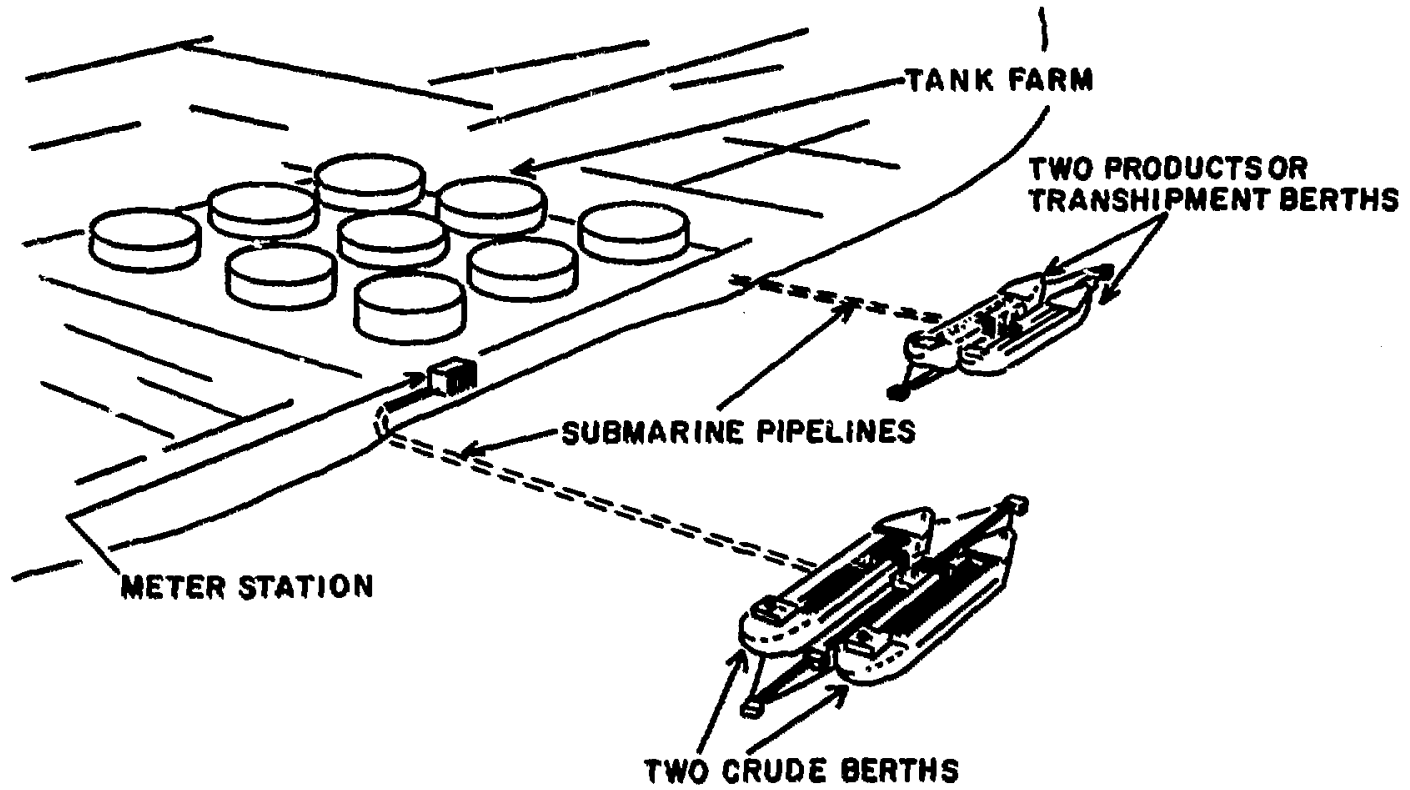

Source: Corps of Engineers as presented in Departinent of Interior, Environmental Impact Statement: Deepwater Ports.

Figure 13. Sea island.

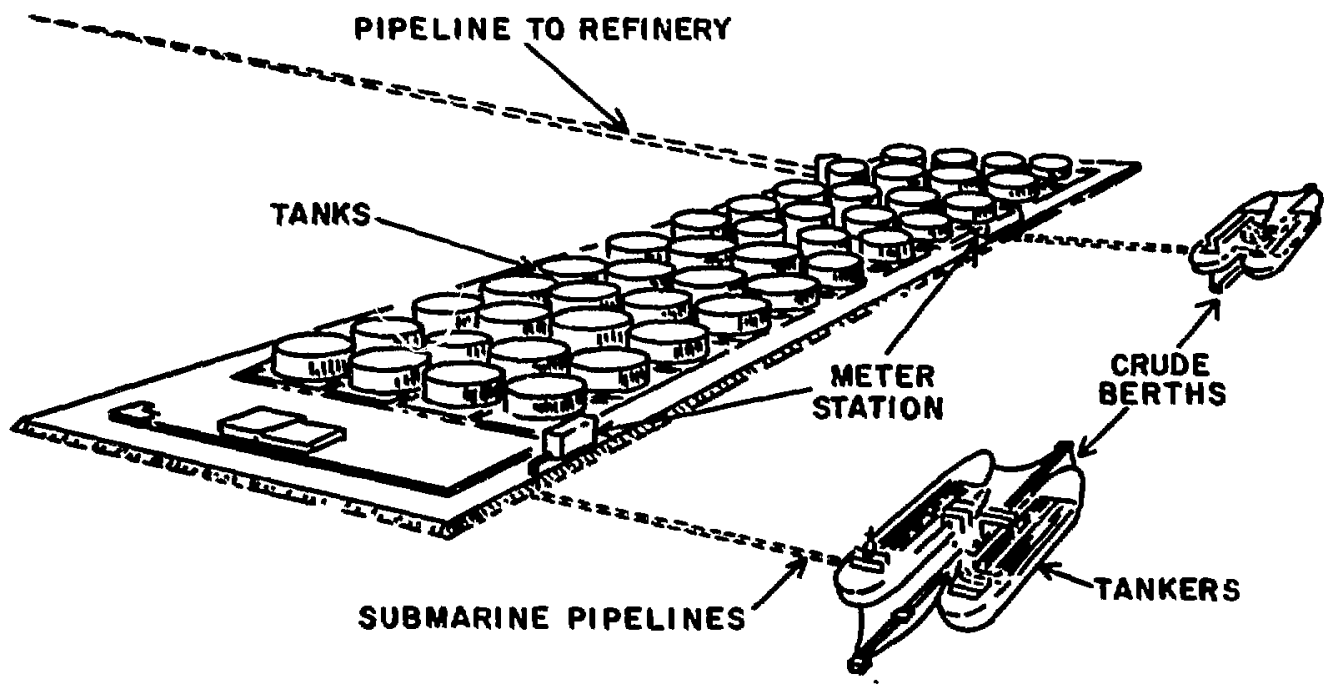

Sonrce: Corps of Engineers, as presented in Department of Interlor, Environmental Impact Statement: Deepwater Ports.

F1gure 14. Artificlal island. 
TABLE 3

COMPARISON OF OFFSHORE DEEPHATER PORT FACILITIES

Type of Facility

1. Single Point Mooring (SPM)

2. Singel Anchor slightly greater Leg Mooring than SPM

3. Conventional Mooring buoy

slightly

greater than SPM

4. Single Pile Mooring Pler

\section{Installation} costs 3-5 times greater than SPM.

5. Floating Platfora 6. Artificial
Island high for a single berth; may be less than SPM for multiberth facility.

approximately equal to that for floating platform.
Sea State

capable of withstanding open seas and heavy weather (Berth: 6-8 foot seas, Hooring: 1520 foot seas.

similar to SPM

unusable in seas greater than $4 \mathrm{ft}$., if orfentation 13 at an angle to waves.

Usable if moored into waves, up to $10 \mathrm{ft}$.

operational in up to $10 \mathrm{ft}$. seas.

can employ breakwater (though cost1y) for operation in heavy seas.

same as for floating plat-

form.
Vulnerability Maintenance

flexible and floating hoses subject to mechanical dawage. Fatigue and corrosion dountime 1 day per month.

hoses simflar to SPM: buoy is very highly resistant to damage from heavy seas and ship action.

"fixed" conditions assure less vulnerability.

hoses less vulnerable than SPM due to replacement of flexible element by solid or trusslike floating arm. Arm subject to damage from higher seas or ship collision.

$\begin{array}{ll}\text { less vulnerable than SPH } & \text { very high flow } \\ \text { due to shorter flexed hoses. through capabil }\end{array}$

less vulnerable than SPM
due to shorter flexed hoses. through capabilities.

least vulnerable due to very high flow

conpletely fixed structures. through capabilities.

\section{Capacity}

low flow through due to long, flexible hoses.

tanker capacity over 500,000 dut; low flow through due to long flex hoses.

tanker capacity 100,000 to 150,000 dwt. Higher fiow through than SPM and SAIM.

flow through much greater than SPM due to shorter and less flexed hose.

less vulnerable than SPM
due to shorter flexed hoses. through capabil 


\section{COST COMPARISON OE ONSHORE AND OFESHORE ENERGY FACILITIES}

Th1s chapter presents information on the comparative costs assoclated with the onshore and of fshore siting of three types of energy facilities: nuclear power plants, deepwater ports, and ofl refineries. Discussion herein will focus on each facility as a discrete unclustered development In order to determine whether or not such a facility is a 1ikely candidate for offshore siting from an economic standpoint. Facilities determined to be likely candidates for offshore siting can thereafter be considered as candidates for of fshore clustering, and included in overall cost assessments of the artificial island concept.

Therefore, this chapter will focus on the second of the six step cost assessment method outlined in the prior chapter as useful for determining the economic feasibility of artificial 1slands for clustering of shore energy developments. This chapter also provides the framework for carrying out the third step of the method, the determination of speciffc costs and benefits which would accrue to each facility proprietor if such facili $y$ were to be clustered on or off shore. This third step in the overall assessment method has not been conducted as part of this study, but can readily be conducted for an actual case, particularly as it can be substantially based on the site-specific factors of cost significance for each facility, which have been identified in this chapter.

At the outset, it should be noted that this generic comparison of an offshore facility with its onshore alternative does not lend itself to a precise or rellable benefit/cost analysis because of constantly fluctuating or unknown economic and regulatory conditions and the high site specificity of many factors. Therefore, this chapter is intended as a broad overview to establish a foundation for future in-depth studies as it is determined that such studies are warranted. The chapter should also help to Identify the Information available, its quality, and the need for additional research necessary to conduct a definitive assessment of the cost feasibility of offshore facilities. 
Cost Feasibility of offahore Nuclear Power

To asaess the cost feasibility of offshore nuclear power vis-a-vis onshore, it is necessary to Identify the major elements or stages of power plant realization; and to evaluate these elements for offshore and onshore cases in order to determine significant cost differences and risks. Table 4 presents the basic elements with brief annotation of their characteristics for offshore and onshore regimes. (23)

A cost analysis developed by the U.S. Council on Environmental Quality ${ }^{(24)}$ comparing the Atlantic Generating Station ${ }^{(25)}$ and an onshore plant indicates that the total costs of the two plants are of the same order of magnitude (Table 5 ).

In order to extend this comparison to a more generalized comparison of onshore and offshore facilities, and to thereby include offshore nonfloating plants, a more detalled look at some of these factors follows.

Table 6 compares the capital cost of an 1150 MWe onshore plant with one equivalent unit of the AGS nuclear plant. The equipment costs for the two plants are (for the purposes of this study) identical. The basic components of the plants are the same: slight differences in costs occur because of 1) modifications in design necessary to facilitate the offshore plant, and 2) the transportation of the major components to the point of assembly. The two factors contributing most to the cost differential are the cost of the labor required in construction and the indirect costs composed of contingency factors, engineering and management, and "other" 1tems.

The considerable difference in power plant construction labor costs $(\$ 103,448,000$ for the onshore plant as opposed to $\$ 71,000,000$ for an offshore plant) may not remain if the plant is constructed on offshore 1slands. The high labor costs for field construction (as opposed to the production-time or pre-fabrication producers used for the AGS) may force labor costs beyond those for an onshore plant. 
TABLE \&

COAPARISON OF BASIC COST ELEMENTS AND THEIR ATTRIBUTES EOR ONSHORE AND OFfSHORE NUCLEAR POWER PLANTS

\section{COST ELEMENT}

1. Site Acquisition for Plant and Transmiasion.

a. avallabllity

b. value

c. acquisition

d. compensation to

abutters and $;$ ihers

2. Englneering and

Investigative costs

3. Site Accessibility and Material Tranaport

\section{Site Preparation}

5. Construction Equipment

6. Construction Labor

a. transportation

b. worker productivity

c. rates

d. special skills

7. Plant Equipinent

8. Cooling Water Systems Design and Construction

9. Anc1llary Fac1lity Construction

10. Transmission Line Construction

OPERATION

11. Product Transtolssion

12. Euel Transportation

13. Radioact Ive Waste DIsposal

14. Environmental Controls: (pollution and waste disposal)

\section{ONSHORE PLANT-ATTRIBUTES}

Land sufficlent for entire plant and exclusion zone (250-500 acres), and in accord with NRC Siting

Guidelines.

Avallable knowledge of how fac1lity will respond in this "known" environment.

May necessitate construction of access roads.

Land clearing, excavation spoll disposal.

"Normal"

"Normal"

"Normal"

Cooling towers probably required, unless exceptions allowed per Water Pollution Control Act. Extensive discharge structures required if exceptions allowed.

Swltchyard

Function of distance to grid hook-up.

Function of distance to grid hook-up.

Land

Onsite storage and/or land transport to of fite storage.

As required by alr, water, nolse and other pollution control laws of federal, state and local authorities,

\section{OFFSHORE PLANT - ATTRIBUTES}

Land sufficlent to locate necesary onshore ancillary factlities, switchyard, warehouse. storage, dock, parking lot, service craft (see also site accessibility).

Seabed sufficlent for support structure for ent Ire plant and sea defense structure probably through ad hoc lease arrangement with approprlate Federal or state authority depending of site, and in accord with NRC Siting Guidelines.

Relative Ignorance of how facility will respond in this "unknown" environment.

Construction storage and transport area and harbor refuge (100 acres) onshore: sea transport vessels, traff Ic arrangements and harbor of fahore.

Discussion of offihore site preparation is deferred to a later section of this study.

Specialized equipment required.

Sea transport costs additional. Also higher wages, and lower productivity.

Corrosion-resistance. Opportunity for standardization per productionline approach to fabrication of of fshore plant equipment.

Once through cooling 11kely, and more readily justified as allowed exception under Water Pollution Control Act. Relatively simple discharge structures.

Warehouse, storage dock, parking lot, in addition to switchyard.

Function of distance to grid hook-up plus composition of subsurface.

Function of distance to grid hook-up distance probably greater.

Land and Water

Land and water transport to of fsite storage.

Same except that amblent nolse laws of state and local authoritles probably not applicable. 
TABLE 5

TOTAL COSTS OF 2,300 MWE NUCLEAR POWER STATIONS ONSHORE AND OFFSHORE (In thousands of dollars) 1973

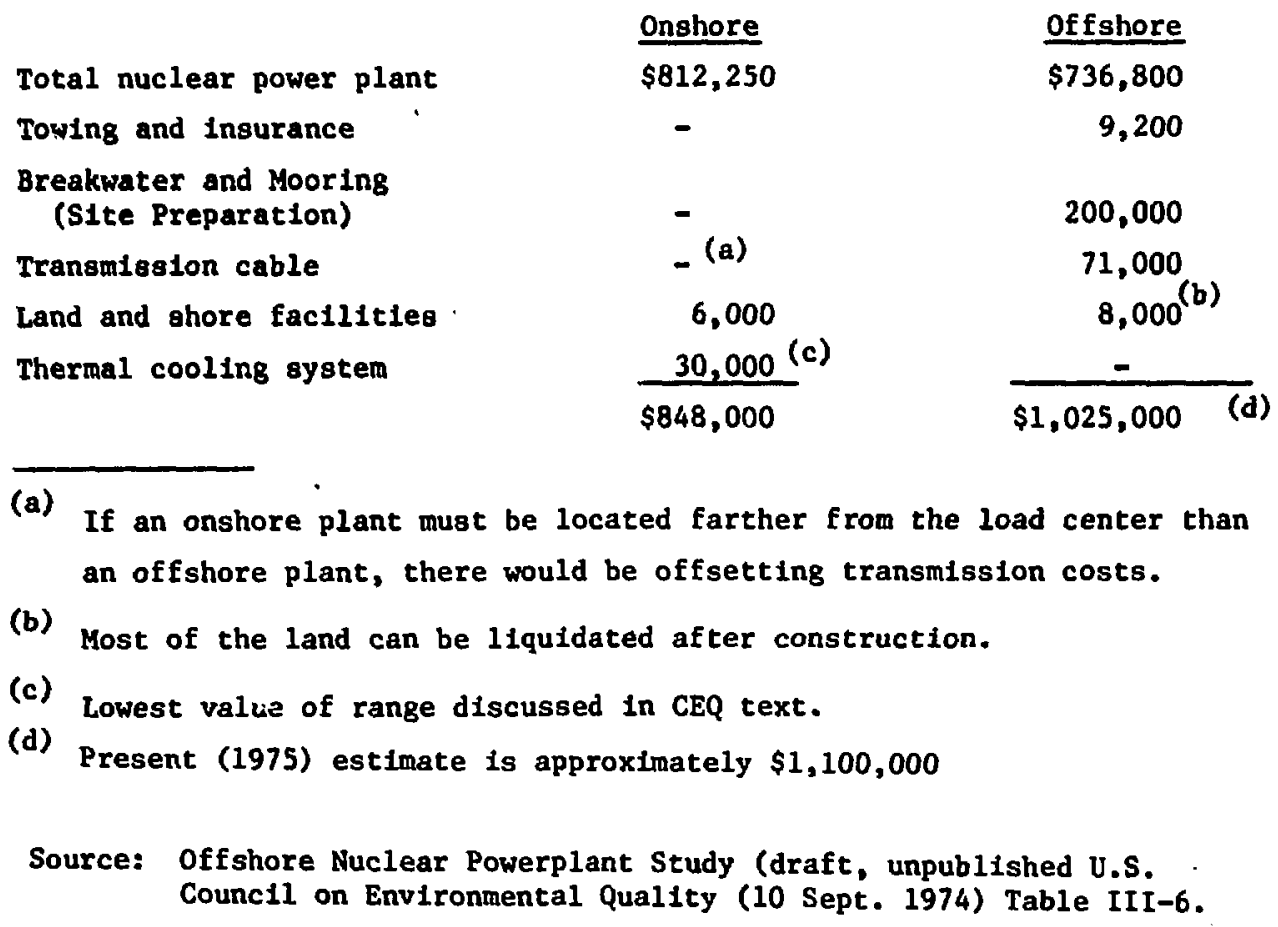


TABLE 6

CAPITAL COSTS OF 1,150 MWe NUCLEAR POWERPLANT ONSHORE AND OFFSHORE (in thousands of dollars)

Equipment

Onshore offshore

Direct costs

Containment structure and facilities

Reactor plant

equipment

Turblne plant

equipment

Electric plant

equipment

Miscellaneous plant equipment

Subtotal

Indirect costs

Contingency

Englneering and

Management

Interest and other

Subtotal

Total
Labor

Total

Onshore offshore Onshore offshore

$\$ 22,087 \$ 21,000 \$ 34,763 \$ 33,000 \$ 56,650 \quad \$ 54,000$

$\begin{array}{llllll}65,541 & 65,000 & 23,909 & 10,000 & 89,450 & 75,000\end{array}$

$\begin{array}{llllll}61,516 & 60,000 & 25,397 & 15,000 & 86,913 & 75,000\end{array}$

$\begin{array}{llllll}14,196 & 17,600 & 16,577 & 9,000 & 30,773 & 26,000\end{array}$

$\frac{2,881}{\$ 166,221} \frac{4,000}{\$ 167,000} \quad \frac{2,802}{\$ 103,448} \frac{4,000}{\$ 71,000} \quad \frac{5,683}{\$ 269,679} \frac{800}{\$ 238,000}$

$$
\begin{array}{rr}
18,656 & 23,700 \\
51,057 & 59,300 \\
\frac{99,662}{\$ 169,375} & \frac{47,400}{130,400} \\
\$ 439,054 & \$ 368,400
\end{array}
$$


There are two basic reasons for this higher cost of offahore labor: lower worker productivity and higher wage raten. At an of fshore site, union contracts might well require that a worker be paid also for the time in transit to and from the onshore dock facility and the offshore site. In addition, if a modest wage differential for of fshore work such as $10 \%$ Is assumed, the total offshore labor cost for a non-floating of fshore plant may range up to $25 \%$ more than for an onshore plant. Hence the more generalized offshore labor cost should be considered as ranging from $\$ 71,000,000$ for a floating plant to cousiderably higher - e.8. $\$ 129,000,000-$ for a non-floating offshore plant.

Indirect Contributions to Cost

Table 6 also indicates a algnificant difference in Indirect costs for offshore and onshore facilitles: contingency and engineering and management costs for the offshore plant are greater than for onshore because of the relatively unknown nature of the ocean environment and the increased difficulty of gathering data. For example, site investigation involves the collection of atmospheric data, which requires that a meteorological tower be erected at the site: it is easier and less expensive to do this on land than in $40^{\circ}$ of water. S1milarly, other of the numerous site Investigation requirements of the Nuclear Regulatory Commission (NRC) can be conducted more readily and at lower cost for an onshore site.

With regard to other indirect costs, the CEQ study (Table 6) Indicates considerable differences in "Interest and other" costs in favor of the offshore facility, based on opinion that an of fshore plant can be constructed, brought on line, and into operation more rapidly than an onshore facility. This opinion is questionable. Indirect factors which Influence the siting and construction of a nuclear power plant, which may determine its ultimate existence and cost but which are very difficult to quantify include permits and licensing, safety concerns, and public opposition.

The process of securing permits for the construction and operation of a nuclear power plant is lengthy, complex and expensive. The of fshore floating plant concept has been clted as enabling a more expeditious permit 
and licensing process by allowing for the simultaneous licensing of plant construction and siting. However, experience with the Atlantic Generating Station (AGS) would seem to dispel this opinion. Unresolved jurisdictional disputes and overlapping authorities necessitates action or review by most of the agencies involved in the onshore case, and several additional authorities with special coastal responsibilities ranging from shellfish protection from radioactive isotopes to safety of ships in transit.

New considerations in the continuing controversy over the safety of nuclear power plant technology are raised by the concept of offshore siting. If a catastrophic accident resulting from fallure of the emergency core-cooling system were to occur In a land based plant, the reactor core would in all likel thood burn itself through the floor of the plant, deep into the ground. The standing plant and earth surrounding the core act as a safeguard against the escape of nuclear material beyond the site and its subsurface area (except for escape via groundwater processess).

However, if an accident of this type were to occur in a floating plant, the release of radioactive material would be rapid and complete; it would be readily dispersed by the sea water. An island-based plant might remedy this to some extent; however sand-filled islands present a problem of their own. When subject to extreme shock, sand can liquify, and this process of liquification under such stresses as may be encountered needs to be seriously assessed prior to locating a nuclear power plant on an artificial sand-filled island.

Another concern with respect to nuclear safety is that of radioactive waste disposal, discussed previously. Except for the transpert of solid radioactive wastes ashore by barge, offshore disposal needs will be identical to those presently required for onshore plants. Again, the study does not enter into the conflict over the safety of present practices; but identifies the added handling and transportation phase for the transfer of radioactive material across the water as an additional risk factor.

Because of provisions for public participation in the licensing process, the fears about nuclear power, and citizen access to the courts, public opposition can play a significant role in plant siting and construction. 
Offshore siting, often considered a panacea to public opponents of nuclear power, does not appear to offer an immediate solution to this problem. The Atlantic Generating Station 18 opposed by many citizens groups which rely on the coagtal region for their 11 velihood and recreation. (26)

Furthermore, because of the AGS' offshore location it is not known what section of the public interest will benefit from revenues. This has led to a different pattern of public opposition from that typically perceived in onshore siting. In the onshore case, people in the immediate vicinity of the plant are generally in favor of the plant because of the tax benefits they expect to reap from Increased revenue which will come from the plant. Those just outside the comnunity boundaries are most vehement against $1 t$, as the revenueg generally do not accrue directly to them, except in the form of jobs and contracts. For the offshore plant, the people most directly affected are those most opposed and willing to work hard to spread their opposition to political representatives. Total Plant Capital Costs

The plant costs discussed above are summarized in Table 7, for onshore, offshore-floating and offshore-non-floating plants of equivalent outputs of 1150 and $2300 \mathrm{MWe}$. Note that because offshore floating plants are Identical, there is essentially no economy of scale and hence two units cost twice as much as one. With respect to the onshore and nonfloating offshore plants, some economies of scale can be assumed and a conservative estimate has been used--that doubling facility output to 2300 MWe increases costs by $85 \%$. As is seen in Table 8 , all three types of plants would incur costs roughly of the same order of magnitude, at either output level.

\section{Total Plant Costs}

\section{Transmission}

Offshore power production requires that a redundant circuit be provided, in case of fallure of one of the others. Hence five circuits, two from each plant and one redundant, are belng planned for the AGS offshore 
TABLE 7

COMPARISON OF CAPITAL COSTS FOR ONSHORE AND

OFFSHORE NUCLEAR POWER PLANTS

(thousands of dollars - 1973)

a) 1150 Mhie (one unit)

$\begin{array}{llll} & \text { Onshore } & \begin{array}{l}\text { Offshore } \\ \text { Floating }\end{array} & \begin{array}{l}\text { Off shore } \\ \text { Non-Floating }\end{array} \\ \text { Equipment } & \frac{166,000}{167,000} & 167,000 \\ \text { Labor } & 103,500 & 71,000-- & 103,000-124,000 \\ \text { Indirect } & \underline{169,500} & \frac{130,400-182,700}{168,400-420,700} & \frac{130,400-182,700}{400,400-473,700}\end{array}$

b) $2300 \mathrm{MWe}$ (two units)

$$
815,000^{(a)} \quad 736,800-841,400^{(b)} \quad 749,000-780,000^{(a)}
$$

(a) Cost of additional 1150 me unit is assumed to be $85 \%$ of the first unit.

(D) Cost of additional 1150 MWe unit is assumed to be equivalent of the first unit.

TABLE 8

COMPARISON OF TOTAL COSTS FOR ONSHORE AND OFFSHORE NUCLEAR POWER PLANTS 2300 Me (thousands of dollars, 1973)

\begin{tabular}{|c|c|c|c|}
\hline FACTOR & ONSHORE & OFFSHOI & \\
\hline Total nuclear plant & 815,000 & $736, \frac{\text { FLOATING }}{800-841,400}$ & $740, \frac{\text { NON FLOATING }}{000-780,000}$ \\
\hline Towing and Insurance & - & 9,200 & - \\
\hline Site Preparation & - & 200,000 & $30,000-200,000$ \\
\hline Transmission Cable & $0-71,000$ & 71,000 & 71,000 \\
\hline Land and Shore Facilities & $6,000-10,000$ & 8,000 & 8,000 \\
\hline Thermal Cooling System & $30,000-120,000$ & - & - \\
\hline Tocals: & $, 000-1,016,000$ & $\$ 1,025,000-1,129,600$ & $\$ 849,000-1,059,000$ \\
\hline
\end{tabular}


generating plant. These additional costs are reflected in the $\$ 71,000,000$ differential cost of offshore transmission shown in Table 5. However, as it pointed out in note (a) of Table 5, the transmission cost is a function of distance from the load center being served, and is thus a highly sitespecific variable. An onshore site distantly removed from the area being served might have transmission costs equal to or greater than those for an offshore plant. Hence to eliminate this site specificity from this generic comparison, a range of costs for onshore sites is used in this study: from $\$ 0$, reflecting the differential unit cost, to $\$ 71,000,000$ a total offsetting the differential transmission cost due to increased distance of transmission.

Land and Shore Facilities

The CEQ estimate of $\$ 6 \mathrm{million}$ for land for onshore sites was based on the assumption of 300 acres at $\$ 20,000 /$ acre. To remove some of this specificity, an area requirement of from 250 to 500 acres is used in this generic comparison with costs ranging from $\$ 10,000$ to $\$ 30,000$ per acre. This yields an onshore land cost estimate of from 2.5 to 15 million dollars.

Land requirements onshore for an offshore plant are very different. A small area, about 15 acres would be required as a permanent base for routine warehouse storage and the shipment of supplies needed at an offshore power station. Further a staging area of approximately 100 acres would be required for construction activities. As indicated in note (b) of Table 5, this land can be liquidated after construction is completed: nonetheless the Inftial capital outlay as shown in Table 5 may actually be greater for an offshore plant if prime coastal land is necessary for the staging area.

The assumption that the seabed for the offshore site will not cost anything may be erroneous, and depends on the actual location. For example, New Jersey law requires that revenue derived from the leasing or sale of submerged lands shall be paid to the Department of Education. Hence, state interests may cause the offshore site to be costly. (23) However, this speculation will not be included for the comparative purposes of this study. Another complicaiton arises when one considers that no developer has ever tried to "buy" an offshore site, and it is doubtful whether the present legal structure could provide for such acquisition or lease, in light of the acreage involved and long term of commitment of the site. 
Thermal Cooling System

The final factor which significanty adds to the cost differential of onshore and offshore sites is the thermal cooling system requirements for waste heat disposal. Though the Federal Water Pollution Control Act (27) recognizes heat as a pollutant, and closed cycle cooling as "best avallable technology", it does permit exceptions from the use of such costly technology and rules and regulations have been published outlining the procedures which are to be followed in the establishment of such alternative effluent limitations. (28)

Hence the posstbility for approval of a less costly once through cooling system exists, and provides an additional incentive for looking to the offshore region. The large amount of sea water avallable for heat dissipation makes this region significantly advantageous to the onshore region where Inland sites having sufficient cooling water are exceedingly rare. In Table 5, the CEQ estimate is a low estimate; the actual range may be as high as $\$ 120$ million depending on the type of closed cycle cooling that may be required for plants sited onshore. It should be noted further that onshore plants on the coast permitted to use once through cooling must Install, in the anticlpated case, extensive discharge systems extending far out from the shore site. Such extensive systems would probably not be required for an of fshore facility, so comparison of on and offshore plants both employing once-through cooling would still restit in lower costs for the offshore facility.

\section{Other Environmental Controls}

other environmental controls, such as radioactive waste systems and other waste and air pollutian controls, would be essentially similar for both on and offshore plants:

"The radioactive waste handling and treatment systems to be installed in floating nuclear power plants are expected to be identical to those in a nuraber of land-based plants presently being constructed. Except for the fact that solid radioactive wastes will be transferred ashore by barge, there should be no major differences between the design and operation of the radwaste system for offshore plants and for landbased nuclear power plants." (29) 
Similarly for air and water pollution, offohore facllitieg will be required to meet the same New Source Performance Standards under the Clean Air Act and effluent IImitations Imposed by the Federal Water Pollution Control Act. It seens that environmental controls, other than those for thermal discharges, will not slgnificantly effect the cost difference between on and offshore plants.

Operating and Naintenance Costs

Since operating and maintenance costs of a nuclear power plant generally amount to only $5 \%$ of annual plant costs, it is doubtful if any difference in this cost element would significantly influence a decision to go offshore. Wages and personnel transportation costs, as well as fuel transportation costs, will drive the operating and maintenance costs for an offshore plant above those for its onshore counterpart: however, for this generic comparison, such differences are not considered significant.

Total Nuclear Plant Costs and Summary of Cost Comparison

The total costs derived from the above discussion for onshore and offshore nuclear power plants are shown in Table 8. As an order of magnitude approximation, offshore nuclear power may prove economically competitive, although any significant economic advantages over onshore plants do not appear likely.

It should be emphasized that these costs are a first order approximation, used only to try to get an overview, for the general case, of whether or not nuclear power on offshore islands should be considered for further study in detail. The actual decision to go of fshore must be basea on a much more detailed cost analysis.

\section{Cost Comparison of offshore and Onshore Deepwater Ports}

Five basic elements contributing to the cost of a deepwater port are 1isted in Table 9 along with a brief discussion of their attributes for onshore and offshore port facilities. Each element is highly case and site specific, and any range of quantitative values to be considered 
COMPARISON OF BASIC COST ELEMENTS AND THEIR ATTRIBUTES FOR ONSHORE AND OFFSHORE DEEPWATER PORTS

COST ELEMENT

1. Dredging

2. Berth and Plpelines to Tank Farm

3. Site Acquisition

4. Tank Farm

5. Pipeline to Refinery

\section{ONSHORE PORT-ATTRIBUTES}

Extensive, some harbors would have to be deepened by up to $50^{\prime}$ or more. Existence of bedrock an additional problem in many areas. Harbors would need widening and lengthening in most cases, as well.

Fixed berth; generally close to tank farm; onshore pipeline less expensive.

Function of size of tank farm, and onshore land prices. Same for pipeline sites.

Little Difference on or offshore

Function of distance to refinery; gerarally closer; onshore pipeline less expensive, unless land costs exceedingly high.

\section{OFFSHORE PORT-ATTRIBUTES}

llost probably none to little dredging of sand and gravel required, as would be dealt with in siting process.

Function of type of berth; and distance to tank farm (offshore or onshore storage); offshore pipeline more expensive.

Function of size of storage area (which may be on or of fshore) and site costs. Same re pipeline sites. Offshore sites for facility to be constructed and pipelines to be leased or acquired from appropriate (federal or state) authority, depending on location, under ad hoc arrangement.

Function of distance to refinery; and site storage (onshore or offshore); offshore pipeline probably more expensive. 
therefore would be quite broad. In addition, there are many other factors (pertaining largely to the environmental and safety aspects of deepwater ports) which have a strong influence on direct and indirect costs. Some of these are summarized in Table 10.

Two extensive studies of offshore ports (by Robert B. Nathan Associates, Inc. (30) and the Councii of Economic Advisors ${ }^{(31)}$, reached similar general conclusions: the extremely high costs, physical construction barrlers, adverse environmental impacts due to dredging and spoil disposal, and the environmental and safety implications of operation appear to preclude the consideration of onshore deepwater ports. If the United States is to continue to rely heavily on forelgn oil imports for its energy needs, offshore deepwater ports may provide the only economically feasible alternative.

\section{Comparison With Existing or In-Construction Facilitles}

The U.S. Deepwater Port Study ${ }^{(30)}$ has reported a comparative analysis of deepwater ports using existing facilities as the base study. For East Coast facilities studied, benefit/cost ratios for the deepwater ports ranged from 1.28-7.50 depending on location, facility design and assumed base conditions.

Evidence exists that superports can provide a highly economical alternative to the use of existing facrlities. Similarly, the study directed by the Council of Economic Advisors ${ }^{(31)}$ reports savings likely to accrue frot the building of a U.S. deepwater port capable of handling oil shipments from distant sources, vis-a-vis the shipping of such oil to deepwater ports presently under construction in the Canso Straits of Nova Scotia and near Freeport in the Bahamas with subsequent transhipment by smaller tankers to U.S. coastal facilities. These results are summarized in Table 11. 
TABLE 10

ENVIRONMENTAL AND SAFETY FACTORS FOR DEEPWATER PORTS

FACTOR

1. Safety "buffer zone"

2. Tankship configuration

3. Water Discharge Facilities

4. Air Emission Controls

5. Aesthetics

\section{ONSHORE PORT}

Extra land may be required for safety zone.

Double-bottomed ships may be required to reduce spillage from grounding.

Subject to regulations under Federal Water Pollution Control Act.

Subject to regulations under

Unpleasant

\section{OFFSHORE PORT}

Surrounding water provides sufficient buffer.

Double-bottomed ships may not be required.

Same as onshore case if sited in territorial sea. Deepwater Port Act of 1974 clearly states, that, even outside the three mile territorial sea, deepwater ports will be considered new sources and subject to enforcement under the Federal water Pollution Control Act. (32)

Same as above for Clean Air Act. (32)

Removed from general view; possibly more pleasing. 
TABLE 11

SAVINGS RESULTING FROM AN EAST COAST U.S. SUPERPORT (cente per barre1)

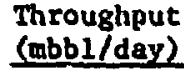

0.600

0.800

1.000

1,135

1.200

1.572

2.000

2.500

3.200

5.1013

6.600
Horst Case (a)

$-4.0$

$-1.6$

$-0.2$

0.4

1.0

3.2

5.3

6.6

7.4

8.1

9.1 (b)

(a) Tankers serving U.S. superports are required to have double bottoms while tankers serving foreign ports are not.

(b)

For the most part, tankers serving both U.S. and foreign ports are required to have double bottoms.

Source: "The Economics of U.S. Deepwater Ports" (Ref. 31).

In order to assure economic viability of a U.S. deepwater port, two provisions must necessarily be met: a large supply of foreign crude oll must be avallable for high throughput, and double bottomed tankers must not be required. The first of these, in conjuntion with today"s complex international political situation has already been discussed. A discussion of the present state of the second factor, the requirement for double-bottomed vessels, follows:

Both the U.S. Environmental Protection Agency and the U.S. Council for Environmental Quality consider the double bottom to be among the 
most Important environmental safeguards necessary to assure reasonable protection against major oil spills. In addition recent accidenta] spills have stirred Congress to possible significant action in this regard: For example, Senator Warren Magnuson has Introduced an amendment to the Ports and Waterways Safety Act of 1972 (46 U.S.C. 391a). This amendment would require all vessels documented under the laws of the United States, on entering the navigable waters of the Unifted States, to meet minimum design criterla including the best available pollution control technology and, if constructed after June, 1975, double bottoms.

This bill, if passed, would place this further constraint on onshore deepwater ports and could, in effect, preclude their construction. It does not appear, at least at this time, that double bottoms would be required on vessels utilizing deepwater ports in the open sea, but the issue has not yet been fully addressed.

In conclusion, it appears that the construction of deepwater ports off the U.S. coast could prove to be beneficlal. However, barriers still exist, the most important of these from an economic standpoint, being the uncertainties of foreign crude supply and the environmental safeguards which would be required in tanker design. These issues must be resolved before a definitive statement on the overall feasibility of deepwater ports offshore can be made. The process of resolution of environmental safeguards has been initiated, and may be completed soon, under Coast Guard authority. (33)

Comparison of Costs of offshore Alternatives

Assuming that it is decided to go ahead with the development of deepwater ports for the United States, the next issue relates to sites and configurations. Table 12 compares annual costs of four alternative facilities, as a function of throughput and the environmental safeguards to be required.

Figure 15 provides estimates of such costs as a function of throughput alone, assuming no environmental safeguards. For this data, It is not possible to draw definite conclusions with regard to the costs 
TABLE 12

Equivalent anNUAL COSTS OF DEEPWATER PORTS SERVIHG THE EAST COAST MARKET

(millions of dollars)

Throughput/Facility

1.135 mbbl. crude/day

Long Branch, monobuoy, pipeline

Cape Kay, sea laland, pipeline

Canada, sea 1sland, tanker

Bahamas, sea island, tanker

\subsection{2 mbbl. crude/day}

Long Branch, monobiny, pipeline Cape May, sea island, pipeline Canada, sea 1sland, tanier

Bahamas, sea 1sland, tanker

\section{$2.500 \mathrm{mbb1}$. crude/day}

Long Branch, monobuoy, pipeline

Cape May, sea island, pipeline

Canada, sea Island, tanker

Bahamas, sea island, tanker

\subsection{5 mbbl. crude/day}

Long Branch, monobuoy, pipeline Cape Kay, sea 1sland, pipeline

Canada, sea 1sland, tanker

Bahamas, sea island, tanker

\subsection{6 mbb1. crude/day}

Long Branch, monobuoy, pipeline Cape May, sea 1sland, pipeline

Canada, Bea island, tanker

Bahamas, sea 1sland, tanker

\section{$6.600 \mathrm{mbb1}$. crude/day}

Long Branch, monobuoy, pipeline Cape May, sea Island, pipeline Canada, sea island, tanker Bahamas, sea 1sland, tanker

\section{No Environmental \\ Safeguards \\ Total Cost D1ffer- \\ per year \\ ential}

382.2

390.9

410.8

417.1

-
8.7
28.6
34.9

419.2

432.2

420.9

424.4

13.0
1.7
5.2

419.2
432.2

432.2

451.4

454.9

13.0

32.2

514.9

521.8

568.8

578.2

-
6.9
53.9
63.3

563.5

575.7

581.6

588.5

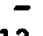

12.2

18.1

563.5

575.7

624.7

630.9

12.2

24.9

i.

872.2

\section{4}

813.0

913.7

926.9

$$
\begin{array}{r}
13.6 \\
114.4
\end{array}
$$

872.2

893.2

932.5

$127.5 \quad 944.2$

21.0

60.3

72.1

893.2

1000.0

1011.8

21.0

127.9

139.7

1109.8

1114.4

1275.0

- 1209.7

$12.7 \quad 1222.4$

$89.1 \quad 1393.6$

$4.6 \quad 1222.4$
165.1

$183.8 \quad 1318.2$

108.5

1412.9

12.7

183.9

203.3

1592.9

1616.0

23.1

1741.3

1856.4

28. 9

1741.3

$151.3 \quad 2030.6$

$186.6 \quad 2061.5$

28.9

1927.9

289.3

320.2

2047.1

2078.1

2411.5

$-$

30.9

2239.8

2276.0

$410.4 \quad 2506.3$

$\begin{array}{rr}- & 2239.8 \\ 36.2 & 2276.0 \\ 219.8 & 2638.0 \\ 266.5 & 2678.1\end{array}$

36.2

398.2

428.3 


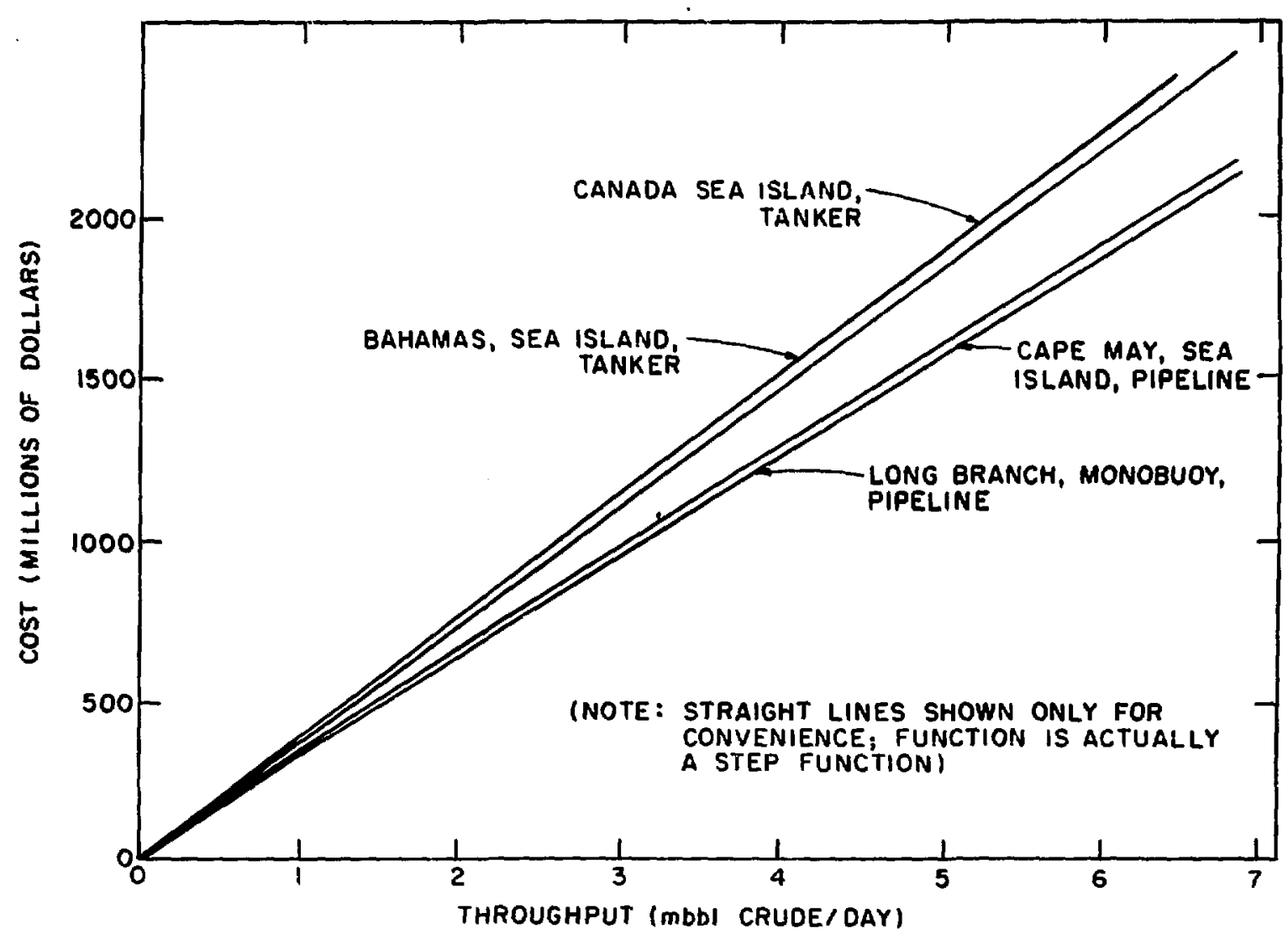

Source of Data: "The Economics of U.S. Deepwater Ports" (Ref. 4).

Figure 15. Comparative cost of 4 alternative U.S. deepwater ports with no environmental safeguards. 
of different port configurations at a particular site. Also, the analysis is based on one configuration only at each site, and hence incorporates numerous site-specific factors sych as sea state, depth of water, and distance to refinery. A relative cost comparison has been provided in Table 13. It appears, however, that under the right conditions almost any configuration is cost-feasible, the cost difference between a Cape May floating platform port and a monobuoy at Long Branch being only about one cent per barrel.

Cost Comparison of Onshore and of fshore O11 Refineries

The case of oil refineries is similar to that for nuclear power plants. However, much less information is publicly available with regard to offshore oll refineries; some have been proposed for the northeast coast, but have not been vigorously pursued. A proposal of interest to this study by Pepco International is for an "energy complex" composed of a deepwater port, refineries and possibly an LNG terminal, to be located on a 225 acre island to be constructed off the coast of 01d Saybrook, Connecticut in Long Island Sound. The profect, consisting of two 200,000 barrel per day refineries, has been estimated to cost on the order of 1.2 billion dollars. $(34,35)$

A list of ten major site-specific factors similar to those presented for the nuclear power p.lant is identified in Table 13. These can be organized into five major components of refinery cost:

1. The refinery plant

2. Land costs and onshore facllities

3. Site preparation (construction on land, island construction)

4. Crude ofl transport pipelines

5. Refined product transport pipelines

\section{Refinery Plant}

Refineries themselves can vary considerably due to the Inherent complextty of the industry. For the sake of this comparison and because 
TABLE 13

COMPARISON OF BASIC COST ELEMENTS AND THEIR ATTRIBUTES FOR ONSHORE ATD OFFSHORE REF INERIES

\section{COST ELEMENT}

1. Site Acquisition

2. Engineering and Investigative Costs

3. Site Accessibility and

4. Sice Preparation

5. Construction Equipment

6. Construction-Labor

a. transportation

b. worker productivity

c. wage rates

d. special skills

7. Plant Equipment

8. Environmental Controls: (pollution and waste disposal)

9. Crude 011 Transport Pipelines

10. Product Transport Pipelines

Land dependent on plant size (300-500 acres) and associated pipelines.

Available knowledge of how a factlity will

respond in this "known" environment.

May necessitate construction of access roads.

Land clearing, excavation and spoil disposal.

"Normal"

"Normal"

"Normal"

Corrosion-resistance; special cooling equipment to be used with salt water.

Legal requirements would in all likelihood be the same, under air, water and noise control laws and their implementation by federal, state and local

duthorities - except that ambient nolse laws of state and local authorities probably not applicable.

Function of distance from port-

storage facility

Function of distance to market center
Function of distance from portstorage facility

Function of distance to market center - distance probably greater 
of available data, the onshore and offshore refineries will be considered to be of equivalent capacity, 400,000 barrels per day, capable of handling the same crude, and producing the same end products. Hence the basic plant equipment will be considered to be the same for both alternatives, However, due to cost differences in engineering, preliminary site investigation, and construction labor, the offshore plant would probably be slightly more costly than the onshore facility. Table 13 and the discussion in the Nuclear Power Plant section of this chapter provide somewhat for the rationale behind this assumption.

\section{Land Costs and Onshore Facilitles}

Site area requirements for a refinery vary with its design and size. The two of Eshore refineries proposed by Pepco would occupy 225 acres; however an equivalent onshore refinery would require an additional buffer zone between 1 t and surrounding facilities. Therefore an area of 300 to 100 acres is assumed for the onshore refinery, at a unit cost of $\$ 15,000-$ $\$ 30,000$ per acre (as developed in the nuclear facility discussion for coastal land). The land cost requirements for an onshore plant would therefore vary from \$4.5-\$12 million.

The onshore land requirements for an of fshore refinery are similar to those for a power plant: a construction staging area on the order of 100 acres which can subsequently be liquidated and a smaller permanent facility consisting of a pumping station, warehouse, storage, dock, parking lot and samll harbor to be contained on approximately 15 acres. The cost for the case of the nuclear plant was estimated at $\$ 8$ million, and 1 s used in this case also. For reasons similar to those discussed in the nuclear plant context, possible land cost savings of an offshore facility site may not materialize.

\section{Site Preparation}

The major aspect of the site preparation element for the offshore refinery case is the construction of the artificial island. Assuming a 225 acre island size requirement, island design and water depth sufficient to accomodate VLCC's, costs could range from $\$ 250,000$ to $\$ 400,000 /$ acre, with the high end of the range being more likely given the water depths desired at such a facility's harbor. Thus the aifferential over the onshore case would range on the order of from $\$ 56 \mathrm{~m}-\$ 90 \mathrm{~m}$. 


\section{Crude 0il Transport Pipeline}

Crude oll transport pipeline costs are highly site-specific, and the cost range too wide to be useful for this study. Since an offshore refinery would probably be located adjacent to or at least in the vicinity of a deepwater port, it could therefore be closer to its source of crude oll than typical onshore refineries. Hence some savings may result with respect to crude oil pipeline costs by siting the refinery offshore and close to the deepwater port. However, as noted earlier, the water depth requirements of the port will add considerably to the costs of constructing an artificial island for a refinery at the same site.

\section{Finished Product Transport Pipeline}

Here too, pipeline cost is highly site specific. Product markets and distribution centers are often hundreds of miles away, and for this reason locations offshore or onshore will make little difference in total pipeline length (perhaps up to 6 miles longer for the offshore case). Therefore, this study assumes no significant difference between the costs of product transport for onshore and offshore refineries.

Cost Comparison Conclusions

Many of the possible cost differences discussed above for generic comparison purposes are described in qualitative terms due to their high site specifity and the lack of publicly available information at this time. Table 14 presents total cost estimates of several proposed New ingland refineries, with the Pepco island refincry more costly than the others. Table 15 summarizes the onshore-offshore cost comparison described herein. The evidence indicates that an island refinery would be more costly, however the difference may not be so great as te entirely preclude of fshore siting of a refinery, particularly in some sorc of cluster arrangement wherein construction and site costs could be allocated among the proprietors of several facilities.

\section{Additional Constraints to Oil Refineries}

As in the case of nuclear power plants, cost is by no means conclusive as to whether or not refineries are to be or should be built either on or 
TÄBLE 14

RECENT. OIL REFINERY PROPOSALS FOR NEW ENGLAND

\begin{tabular}{|c|c|c|c|c|c|c|c|}
\hline Company & Ref1 & $\begin{array}{l}\text { nery Capac1ty } \\
\text { (barrels } \\
\text { per day) }\end{array}$ & $\begin{array}{l}\text { Port } \\
\text { Fac1l1ty }\end{array}$ & $\begin{array}{l}\text { anker size } \\
\text { (1n dead } \\
\text { wt.tons) }\end{array}$ & $\begin{array}{l}\text { Est Imated } \\
\text { Cost }\end{array}$ & Products & $\begin{array}{l}\text { Anticipated } \\
\text { Market }\end{array}$ \\
\hline $\begin{array}{l}\text { The P1ttston Co., } \\
\text { New York }\end{array}$ & $\begin{array}{l}\text { Eastport, } \\
\text { Malne }\end{array}$ & 250,000 & $\begin{array}{l}\text { Originally: } \\
\text { f1xed pler }\end{array}$ & $\begin{array}{l}150,000 \\
\text { to } \\
250,000\end{array}$ & $\$ 450$ mil110n & $\begin{array}{l}\text { Propane, butane, } \\
\text { gasollne, No.2 } \\
\text { and No.5 fuel ofl }\end{array}$ & $\begin{array}{l}\text { New England, } \\
\text { New York C1ty }\end{array}$ \\
\hline N.E. Energy Co. & $\begin{array}{l}\text { Sanford, } \\
\text { Maine }\end{array}$ & 250,000 & $\begin{array}{l}\text { Coastal tanker } \\
\text { terminal in } \\
\text { Portland, Me. }\end{array}$ & & $\$ 650$ million & $\begin{array}{l}\text { Gasoline, No. } 2 \\
\text { and No.6 fuel } \\
\text { o11 }\end{array}$ & Nes England \\
\hline In-0-Ven Corp. & $\begin{array}{l}\text { Montvitle, } \\
\text { Connecticut }\end{array}$ & 400,000 & $\begin{array}{l}\text { offshore } \\
\text { supertanker } \\
\text { port }\end{array}$ & $\begin{array}{l}200,000 \\
\text { to } \\
250,000\end{array}$ & $\$ 500$ million & $\begin{array}{l}\text { Gasoline, kerosene } \\
\text { jet fuel, butane } \\
\text { No. } 2 \text { and No.6 } \\
\text { fuel oil }\end{array}$ & $\begin{array}{l}\text { New England } \\
\text { pipeline to } \\
\text { Boston and } \\
\text { Springfield }\end{array}$ \\
\hline PEPCO & $\begin{array}{l}\text { Off old } \\
\text { Saybrook, } \\
\text { Conn. }\end{array}$ & $\begin{array}{l}200,000 \text { each } \\
\text { of } 2 \\
\text { fac111tieg }\end{array}$ & $\begin{array}{l}\text { Island refin- } \\
\text { ery, super } \\
\text { tanker port } \\
\text { complex }\end{array}$ & 250,000 & $\$ 1.2$ b111ion & $\begin{array}{l}\text { Gasoline, kerosene } \\
\text { jet fuel, synthe- } \\
\text { tic natural gas, } \\
\text { No. } 2 \text { and No.6 } \\
\text { fuel ofl }\end{array}$ & $\begin{array}{l}\text { Connecticut } \\
\text { possibly Rhode } \\
\text { Island and } \\
\text { Massachusetts }\end{array}$ \\
\hline Olymp1c & $\begin{array}{l}\text { Newmarket, } \\
\text { New Hampsh1re }\end{array}$ & 400,000 & $\begin{array}{l}\text { Offshore deep- } \\
\text { water port }\end{array}$ & $\begin{array}{l}250,000 \\
\text { or } \\
\text { larger }\end{array}$ & $\$ 600$ million & $\begin{array}{l}\text { Gasoline, 1iqui- } \\
\text { fied propane } \\
\text { gas, No. } 2 \text { fuel o1i }\end{array}$ & New England \\
\hline $\begin{array}{l}\text { Grant te State } \\
\text { Refineries Inc. }\end{array}$ & $\begin{array}{l}\text { Rochester, } \\
\text { New Hampsh1re }\end{array}$ & 400,000 & - & - & - & - & - \\
\hline $\begin{array}{l}\text { Fireline } \\
\text { Petroleum co. }\end{array}$ & $\begin{array}{l}\text { Massachusetts } \\
\text { or } \\
\text { Rhode Island }\end{array}$ & $\begin{array}{l}100,000 \\
\text { to } \\
200,000\end{array}$ & $\begin{array}{l}\text { Deep Water } \\
\text { port }\end{array}$ & - & $\begin{array}{l}\$ 100 \text { million } \\
\text { to } \\
\$ 200 \text { m11lion }\end{array}$ & $\begin{array}{l}\text { Gasoline, No. } 2 \\
\text { and No.6 fuel } \\
\text { o11 }\end{array}$ & Northeast \\
\hline $\begin{array}{l}\text { Name Unknown } \\
\text { (Promoted by } \\
\text { Paul Cronin) }\end{array}$ & Dracut & $\begin{array}{l}200,000 \\
\text { to } \\
250,000\end{array}$ & $\begin{array}{l}\text { Deep water } \\
\text { port off Bogton } \\
\text { pipeline to } \\
\text { Dracut }\end{array}$ & n & $\$ 500$ million & $\begin{array}{l}\text { Gasoline, Kerosene } \\
\text { No. } 6 \text { fuel o:1. } \\
\text { petrochemical } \\
\text { feed-stocks }\end{array}$ & $\begin{array}{l}\text { Massachusetts } \\
\text { New Hampshire }\end{array}$ \\
\hline
\end{tabular}

Source: Boston Globe, 23 Apr11, 1975. 
offshore. This is especially true in New England where 15 refineries have been proposed since 1958, but none have been bullt. It is doubtful whethe: moving them of fshore will obviate significant opposition. It is for this reason that more effort has not been put into the Pepco island refinery proposal and that the State of Connecticut has treated the proposal cautiously. Although technically and economically feasible, environmental and need factors will have to be more closely considered before decision on offshore oil refineries can be made.

TABLE 15

ONSHORE-OFFSHORE OIL REFINERY COST DIFFERENCES

(millions of $\$)=(400,000 \mathrm{Bl}$, per day $)$

1

COST ELENENTS-

1. Refinery Plant

2. Land Costs and

Onshore Facilicles

3. Site Preparation

4. Crude O1l Transport Pipeline

5. Refined Product Transport Pipeline
ONSHORE

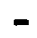

$\$ 4.5-12$

$-$

highly site specific probably more costly onshore

hlghly site specific - no slgniflcant difference assumed in this study.

\section{OFFSHORE}

slighcly more costly

$\$ 8$

$\$ 56-90$

$-$ 
Chapter V

CLUSTER VS. DISPERSED SITING

This chapter presents a discussion of the economic costs and benefits that could accrue from siting the three types of energy facilities discussed, either of fshore-dispersed or offshore-ciustered. No attempt is made to offer comparisons with onshore-dispersed and onshore-clustered configuration alternatives.

Therefore, this shapter focusses on the third and fourth of the six step cost assessment method outlined in Chapter II. The discussion also Includes an analysis of costs for the island itself based on information and concepts presented in all the foregoing chapters. This latter aspect of the chapter therefore contends with some of the tasks determined to constitute the fifth step of the overall cost assessment method, but does not contend with the floating 1sland and natural island as offshore alternatives, nor does it provide a detalled analysis of the onshore power park configuration: it is limited largely to treatment of the land fill island alternative, which is the major concern of this study.

\section{Basic Concepts for Evaluation}

The decision whether to cluster the three facilities studied on a single offshore site, or to disperse them on their individual offshore sites, involves a number of variables. Some of these considerations are inherent in comparisons of the cluster-siting concept with dispersed siting alternatives, regardless of the specifics of the factlities in question; other variables are highly facility-specific; still others involve a combination of both. Two generalized variables which enter into this siting decision, due to the basic attributes of the concept are a) the economies of scale associated with construction of the site, and b) the allocation of costs for use of shared facilities.

\section{Land Costs}

While onshore land costs vary from location to location, one assumption can reasonably be made concerning onshore land costs; 
that at a particular site, the cost per acre is roughly a constant, Independent of the amount of land being purchased. Hence with regard to onshore cluster-siting vs. onshore dispersed siting there are no significant Inherent economies of scale for land. The only important variable is therefore the unit cost of the land at the particular sites in question.

The offshore case is very different, and offshore 1sland construction exhibits large economies of scale. To 1llustrate this consider the main components of the costs of building an 1sland: the costs incidental to the filling process to create the 1sland, $c_{1}$, and the costs incidental to the construction of the sea defense, $\mathrm{C}_{2}$. The total cost, $C$ is therefore

$$
c-c_{1}+c_{2}
$$

It is desirable to express each of these as a function of the area of the island being created. The cost of bullding the sand body, $c_{1}$ is composed mainly of the dredging activity including assoctated transport of the $f 111$, and hence is a function of the amount of $f 111$ material. Therefore $c_{1}$ can be roughly estimated as follows:

$$
C_{1}=A d P_{1}
$$

where $A$ is the area of the 1sland,

d the average height of the 1sland surface above the original seabed.

$p_{1}$ is the average cost per unit volume of fill materlal dredged and transported.

The cost of constructing the sea defense wall $\mathrm{C}_{2}$ can be roughly assumed to be proportional to the perimeter of the island, that is, to the length of the wall to be bullt. Therefore:

$$
C_{2}=L p_{2}
$$

where $L$ is the perimeter of the 1sland

$p_{2}$ is the cost per unit length of sea defense wall 
However $L$ can be shown to be equal to $\alpha \sqrt{A}$ where $a$ is a constant depending on the shape of the island. Therefore:

$$
C_{2}=\alpha \sqrt{A} p_{2}
$$

And

$$
C=A d P_{1}+\alpha \sqrt{A} P_{2}
$$

Figure 16 shows a plot of these costs, $C_{1}, C_{2}$ and $C$ as a function of area. Figure 17 shows a plot of the unit cost, that is the coet/area as a function of area. Note that as the area increases, the unit cost greatly decreases. It is this advantage which cluster siting has over dispersed siting in the offshore region. Figure 18 shows some actual cost estimates made for the North Sea Island profect reflecting these cost assumptions.

These suggest that for large scale profects, artificial lslands may be an economically viable alternative.

Shared Facilities

The sharing of facilities common to all of the activities on the island can eliminate duplication of effort and cost throughout the course of the project, from initial planning through to operation. Likewise, the use and costs of many of the ancillary facilities required by the on-going activities on the island can also be shared. Such necessities as transportation, water purification, communication, safety (e.g. fire protection) and waste disposal facilities can be jointly met. Although the capacity of these facilities must be increased to ensure that each share will be adequate, economies of scale will again enter to produce savings. This benefit can be extended to necessary services as well--if workers are to reside on the island, community services such as recreation can be jointly provided and paid for.

Facility-Specific Effects of Cluster Siting

In addition to the benefits discussed above which inhere in the cluster concept, other factors must also be considered when the specific nature of the facilities proposed for clustering is determined. These factors include special siting regulations (e.g. with respect to nuclear 


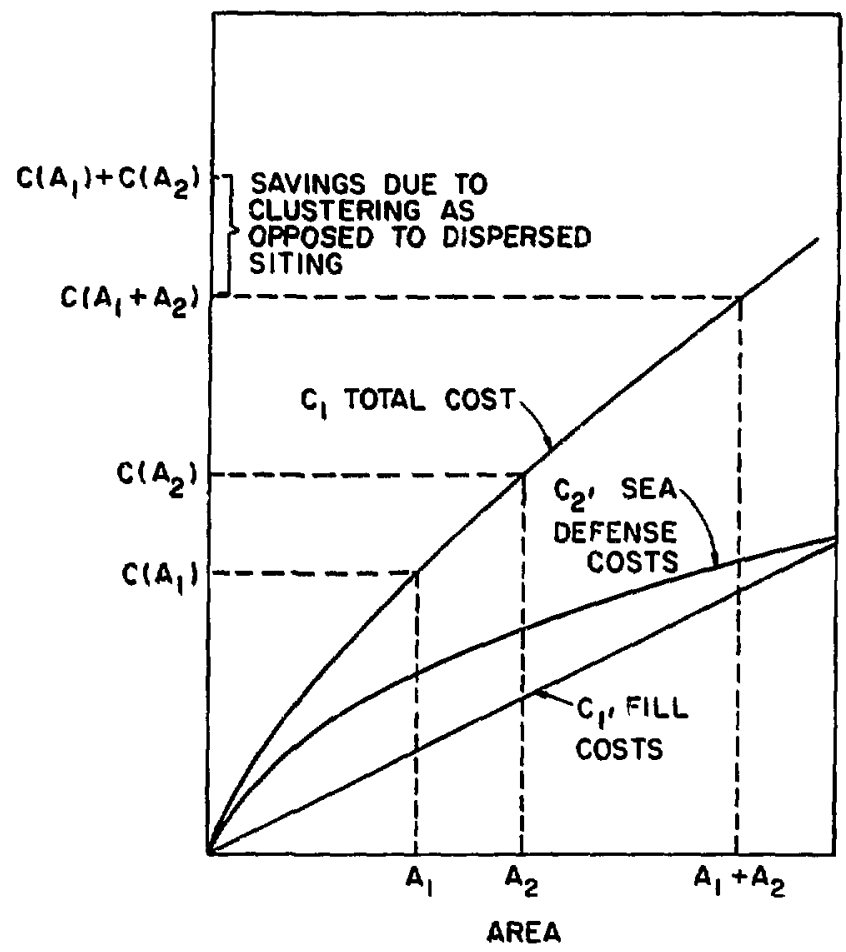

Figure 16. General relationships between $C_{1}, C_{2}$, and $A$. 


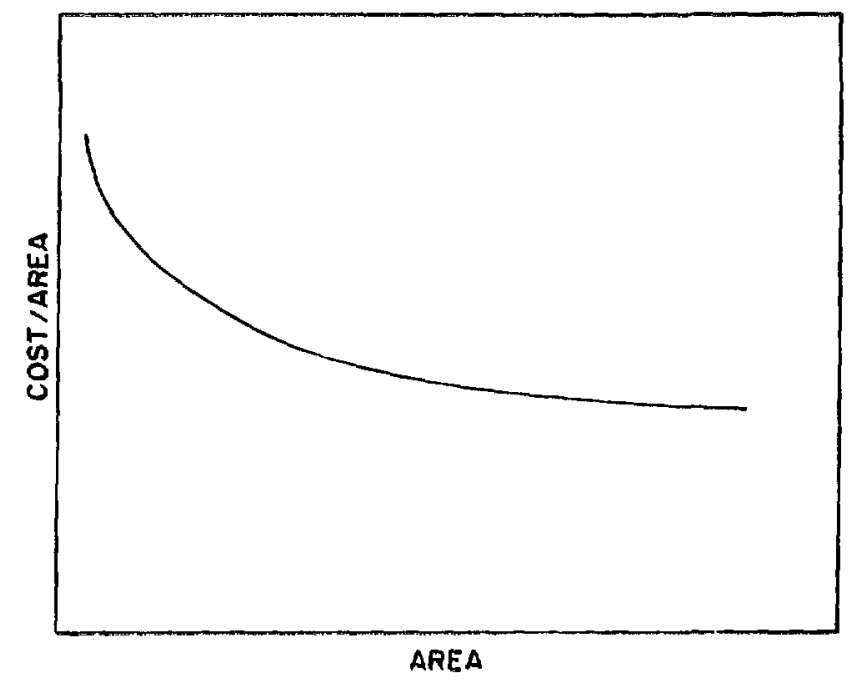

Figure 17, Cost/area as a function of area.

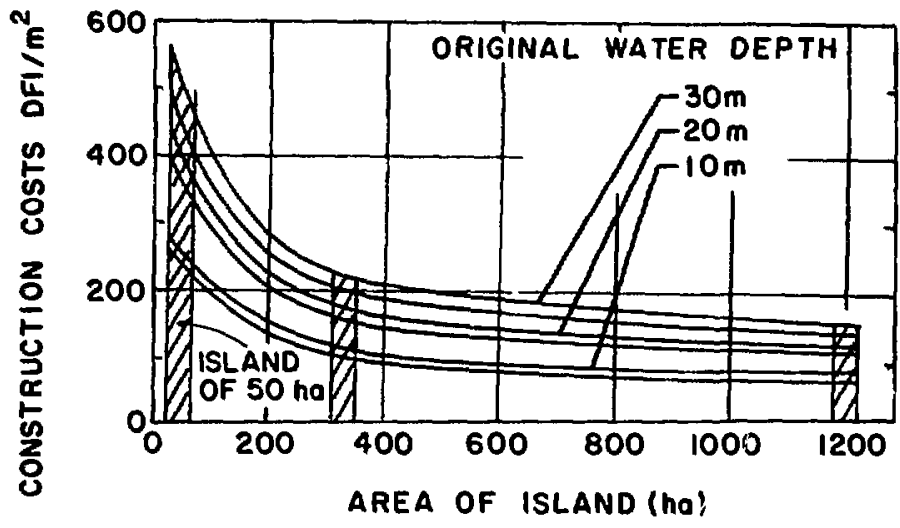

Source: Bos Kalis Westminster Dredging Group, "Sea Island Project."

Figure 18. Construction costs related to the area of the island and water depth. 
power plants and the co-location of potentlally hazardous facllities), amblent standards for alr, water and nolse which will determine to some extent the degree of environmental pollution control required of each facility, and coordination of facility proprietors with respect to the reuse and management of residuals.

Industrial centers presently in operation in the United States have demonstrated the possible dangers of pollution and explosive hazards which can result from locating numerous industrial activities in close proximity. The siting of nuclear power plants is governed by regulations requiring the extablishment of an exclusion area (37); requiring that the utility owning the plant must have "...authority to determine all activities including exclusion and removal of personnel and property from the area" ${ }^{(38)}$; and requiring special consideration in regions "...containing...Installations or operations which may pose a threat to the nuclear power plant operation, and in turn to environmental protec:tion..." (39)

These regulatory requirements have direct implications for the sharing of facilities, management responsibilities and legal duties. While the NRC may allow the siting of a nuclear power plant on a multi-purpose Island, the additional requirements for the exclusion area and design Improvements for accident prevention would definitely add to the cost of the plant, and possibly render it unfeasible for such siting configuration.

Several other restrictions impose requirements which also merit consideration for the cluster complex. First, offshore facilities will in all likelihood be considered "new sources" under the clean Air Act and the Federal Water Pollution Control Act and will therefore be subject to New Source Performance Standards in regulating atmospheric emissions and the "best practicable" and "best available" technology requirements in regulating water pollution. Second, the Federal Water Pollution Control Act imposes requirements for stricter emissions controls to meet ambient water quality standards where a number of similar facilities, with similar emissions, are located at a single site. Third, the courts have determined that the Clean Air Act requires strategies to prevent "significant deterioration" of the quality of air in regions in which the air is 
purer than that which would be achieved by the amblent standards $(10)$ Whether or not these last two sanctions would be Imposed depends on the specifics of the island and facilities in question, the actions of the administrator of the Environmental Protection Agency and the resolution of challenges to the "significant deterioration" regulations. (41). Some of these regulatory considerations in the development of offshore facilities are discussed in the companion volume to this report: Backstrom, T. D. and Baram, M. "Artificial Islands for Cluster-Siting of Offshore Energy Factlities: An Assessment of the Legal and Regulatory Framework", BNL-50566, June 1976.

\section{Industrial Coordination}

As mentloned above the clustering of many similar industries bears potential environmental problems; however, if these industries are well chosen and coordinated, much of this problem could be alleviated. The concept of residual reuse and subsequent waste minimization is becoming increasingly important. For example, incorporation of recycling into island planning offers a promising alcernative to more traditional pollution controls.

The industrial complexes presented in the University of Delaware study demonstrate technological possibilities for the reuse of waste. The possibilities of waste water reuse and waste heat utilization are numerous and should be given consideration in planning any multi-facility island as a means of off-setting potential environmental problems and constraints; yet it will not be the sole criterion in deciding what to site on an island complex, as there must also be a legitimate need for the products to be produced by the facilities in question.

Additional Siting Trade-0ffs

The siting of a single facility in a cluster configuration requires a number of trade-offs; and a brief list of criteria which would figure in such trade-offs for the three facilities under consideration is shown in Table 16. The criteria for the siting of the island itself to house these facilities is also included in Table 16.

The conflicts that arise in the site selection process, and hence the trade-offs that must be made, exist on three levels: intra-facility inter-facility, and factlity-island. 
TABLE 16

SITING CRITERLA FOR ISLAND COMPLEX

\section{Factlitles}

Nuclear Power Plant

Proximity to load center

Distance from population center

Suffictent cooling water

Geologic stablifty (foundation, selomiclty, etc.)

Environmental/ecological features

Deepwater Port

Sufficient water depth

Sea State

Proximity to shipping lanes

Proximity to refinery

Environmental/ecological features

Refinery

Proximity to crude oll supply

Proximity to refinery product market

Sufficlent cooling and process water

Environmental/ecological features

Island

Water depth

Proximity to construction material (quarry stone, offshore sand and gravel)

Sea state

Tidal and current influences

Environmental/ecological impact at site

Shipplng and military activities in region 
Intra-facility conflicts are those which exist due to the siting of a single facility; an example of this is the necessity in the siting of a nuclear power plant to locate near a load center, and at a suffictent distance from a population center. In actuality the load center and the population center may be in very close proximity, resulting in a balancing task among conflicting economic and safety objectives.

Facility-island conflicts are those which exist due to the fact that a single facility is located on an island. The most obvious of these is the conflict over water depth in dealing with an island-based deepwater port. In order to facilitate easy access to the port by large deepdraft supertankers a deep channel is required. However in order to minimize island construction costs, it would be more desirable to locate the island in an area of shallow water depth. This conflict can be reduced somewhat if the site also meets the criterion of proximity to of and gravel deposits. In that case it might be possible to dredge channels, and simultaneously provide material for the construction of the island.

Although neither of the above type of conflicts for trade-off are a function of cluster siting, inter-facility siting conflicts are. This type of conflict can in some cases be beneficial, while in others it can be detrimental. The obvious beneficial aspect of cluster siting is the result of facility interaction, in which one facility would use the product of another as an input material. This is demonstrated by the proximity of a refinery to a deepwater port.

In general, the cluster concept will probably result in zero or negative sum trade-offs which must be dealt with; what is beneficial to a certain facility will be detrimental to another. This is most obvious if the facilities are producing products which have endproduct markets in different locations. One or each of the facilities will have to pay for being moved from its optimal site (as a single facility), due to the additional siting constraints imposed by its island companions. A relative comparison of facturs influencing the discrete or clustered siting of facilities is shown in Figure 19. 


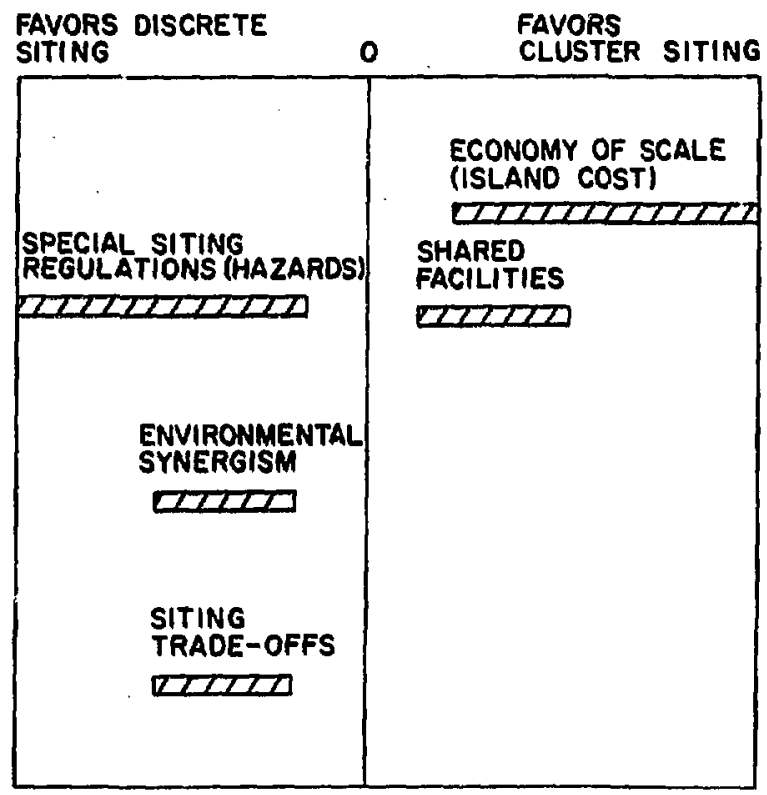

Figure 19. Relative comparison of factors influenced by cluster and discrete siting. 
Chapter VI

FINANCIAL ALTERNATIVES

This chapter concludes the cost feasibility assessment for the multi-facility land fill island which was outlined in Chapter III by providing some general remarks on the sixth and final step of considering alternatives for financing island construction. Basically, three types of funding arrangements are considered: totally private, totally public, and a combination of the two.

\section{Tutally Private Financing}

Technological innovation in this country has traditionally been the province of private enterprise, but since the second World War this trend has been shifting. The federal government now plays the primary role in the development of large scale technological advances particularly In the fields of energy and transportation where private sector research has atrophied. The future of privately-funded offshore energy facilities may well be determined by the first such case proposed, the AGS floating nuclear power plant: if it succeeds, other private companies may follow suit. However, fallure may well inhibit of fshore siting, except possibly for deepwater ports, by private parties, for the foreseeable future.

The AGS project is presently in a self-imposed 5 year period of delay, for several alleged reasons: a downturn in energy requirements; financing problems arising from the present economic situation with its high interest rates; and, regulatory and licensing uncertainties.

The possibility of several private interests coming together, to share the planning costs and benefit from the economies of scale in developing a multiple-facility artificial island are presently remote. There is little American experience to call on in implementing a private joint venture on such a large scale project. Traditionally, such approaches in the United State have involved a strong federal lead agency, and the provision of federal funds or at least federal assumption of risks and possible liabilities. ${ }^{(42)}$ 
The legal context surrounding the concept of artificlal islands is very uncertain: the concept is new and the present legal structure may not be adequate to protect private and public interests at stake. Given these uncertainties and adverse cunditions, the prospect of totally-private funding for capital investment is not too promising. Federal leadership and financing will in all likelihood be needed to implement the concept.

Totally Public Financing

The concept of total public financing runs contrary to the American capitalistic system. With few exceptions such as TVA, the government has not entered into the ownership and operation of energy facllities for private consumers, despite numerous Indications that such a federal role must be developed. In fact, it appears that the most important pressure on the federal government to develop such a role may now emanate from Industrial firms involved with the troubled AGS venture. (43)

It is unlikely that any federal agency would attempt to finance the total cost of constructing such an island, even as a demonstration profect, because of 11 intations of authority and probable congressional reluctance to rely on a single agency as developer for such a facility with its numerous implications for many different agencies. Therefore, a consortium or interagency task force, or a public corporation such as COMSAT, would appear to be the most likely forms for a federal development effort. Also in the Congress itself, a special comittee such as the Joint Committee on Atomic Energy, with assistance from a speclally-constituted group or professional staff such as the Ocean Policy Task Force, would have to be considered among other alternative structures to enable Congress to oversee and control the overall effort.

Total federal funding is therefore a prospect of considerable complexity, and as it is the most feasible form of financing such a large scale development on a demonstration basis (and subsequently, perhaps on a program basis), considerable research into prior Congressional and Executive arrangements of relevance (such as COMSAT, TVA, etc.) should be undertaken. The research should focus on the management, legal and policy aspects of the federal role needed to carry out island development and management. 
These remarks on public financing could be similarly extended to other levels of government, such as state, regional and municipal-metropolitan. Joint Private and Public Financing

An integrated effort between private interests and the federal government appears to pose the most feasible solution to the financing of a large scale artificial island project. Exactly how this could be worked out is left open for further study.

One basic idea which should be assessed is to have the federal government construct and retain ownership of the island, provide federally-subsidized insurance coverage for large scale hazards such as explosions, and further provide expressly for private liability for pollution effects and other lesser-order unintended effects. Site location and island configuration must of course incorporate the interests of the Industries, and private financing used for realization of the energy factlities on the 1sland. After construction of the 1sland, tracts could then be longterm leased to the various facllity developers. This arrangement may help to eliminate some of the implementation problems mentioned above. To sum up these possible federal functions:

1. The heavy burden of the initial capital expenditure would be borne by the federal government.

2. The essential lead role in integrating the parties and overall effort necessary to make the project run to completion, would be borne by the federal government.

3. Liability for rlsks, from hazards of a catastrophic nature to accidental and relatively harmless spills or discharges, would be clearly allocated in accordance with the desired performance required of industry and the financial capabilities of the private and public sector parties.

This discussion of financing alternatives merely opens up the issue for further study. Such study could reveal that the federal role suggested could be borne, at least in part, by authorized industrial consortia or by state and even local levels of government. As states develop regional institutions for resolving energy problems, financing 
and planning responsibilities could be delegated to such reglonal authorities. Given the flexibility of financing in the United States, and the scope of federal authority under the constitutional criteria of interstate commerce or national security to meet natlonal or interstate needs, financing issues can be resolved if there is adequate leadership in approaching the multiple-factlity island concept. 
Chapter VII

CONCLUSIONS

This study has presented a general first-order cost feasibility analysis of the artificial island concept and its usefulness for the offshore siting of multiple energy facilities. The results of this study include a recommended method of cost-feasibility assessment, upon which the several analytical chapters of this work are based; the collection and organization of the most useful information presently avallable; and a series of conclustons on feastbility for generic comparison purposes. These conclusions can be summarized as follows:

1. Artificial Islands to the outer bound of the continental shelf are technologically feasible. The tecnuology for the creation of such artificial islands exists, is presently being applied to relatively small scale projects, and in the near future will see increasingly larger scale applications.

2. Offshore nuclear power plants appear to be competitive with onshore plants from a cost standpoint. However environmental and safety concerns, public opposition, and legal uncertainties may prove to be significant impediments to their development.

3. Offshore deepwater ports appear to be more economical than proposed onshore deepwater ports, existing facilities or facilities presently under construction. However, essential to this conclusion are a) the assurance of a continuing large supply of foreign crude oil or crude oil from U.S. of fshore resources; and b) an assumption that the required environmental controls will not include the use of double-bottomed tankers.

4. Offshore oil refineries, except under special circumstances, will probably be more costly than onshore counterparts. Intense localized resistance has arisen in New England to any refinery proposals, and this local resistance is at this time the major constraint to their siting either on or off shore.

5. The cluster-siting of facilities on an artificlal island has definite cost-effectiveness potential. The major reason for 
this is the economies of scale of large 1sland construction. The major deterrent at this time 18 the risk in the clustersiting of hazardous facilitles.

6. A joint public-private financlal venture with a strong federal agency lead role appears essential for the multi-facility 1sland concept to be realized.

7. Artificial island siting of energy complexes appears to be a concept worth pursuing in terms of further site and facilityspectfic research, and possibly in terms of a demonstration project.

Among the spectflc matters which need to be addr sed in detall are:

1. Innovations in factlity design and coordination to make more efficlent use of the valuable island land, and to promote recycling of wastes.

2. Environmental effects which will arise from the construction and operation of such an 1sland, Including secoindary effects onshore.

3. Measures for the efflcient management of construction in order to reduce construction costs, times, and externalities.

4. Methods for the selection of compatible facilities to be clustered.

5. Methods of financing.

of paramount importance are several larger social issues which must be addressed in an appropriate national forum:

1. What are the potential effects (environmental, economic, social) of developing an artificial island-based energy program? Is it another short-term technological fix; a technological solution to a non-technical problem? As we are now beginning to realize the finite quality of terrestrial resources, is the artificial island simply a short-term solution which will engender new, more intractable problems, which simply postpone facing this larger realization with a systematic and sound global strategy? A full scale technolugical assessment should be carried out in an effort to deal with these questions. The growth and power implications of creating land must not be avolded in considering the concept. 
2. What type of institutional framework will be required to carry out such a program within the constraints of the legal, economic, and social systems and values of the United States? How can the various actors and interests be integrated to establish a harmonized effort, and to otherwise avoid hayhazard development offshore which would replicate the landward experience? ${ }^{(44)}$

Above all the most basic question has to be addressed: is there a need for multiple-facility artificlal islands? Application of a concept is not justified simply because technology is avallable and the economlcs are acceptable. Are the onshore constraints to siting arbitrary and a real detriment to our soclety, or are they a warning of deeper realities that we must proceed with restraint and conservation towards our energy future? 
REFERENCES

1. Palmedo, Ph1ll1p F., "Approaches to Reglonal Energy Analysis", Growth and Change: A Journal of Reglonal Development, Vol. 7, No. 4, Oct. 1976.

2. Stigter, C. "Dredging and Land Reclamation" in North Sea Spectrum, K.0. Troup, ed., Reed (London), 1972.

3. Sea Island Project: The Bullding of Islands in the Open Sea Offers Possiblilties for Industrial Development, Bos Kalis Westminster Dredging Group, N.V., Papendrecht, Holland, June 1972.

4. Bonagia, J.J. An Evaluation of Multi-Purpose of fshore Industrla1/Port Islands for the Atlantic and Gulf Coast - Civil Engineering Considerations, (Draft Report) prepared for NSF/RANN by Frederic R. Harris, Inc,, Jan. 1975.

5. Sea Island Project: A Solution for the Waste Disposal Problem, Bos Kalls Westminster Dredging Group, N.V. Papendrecht, holland, June 1972.

6. Braum, Jonathan, "Jacques Coustcau's Man-Made Islands", Parade, March 16, 1975, p. 16.

7. Bechtel Corporation, Engineering and Economic Feasibility Study for a Combination Nuclear Power and Desalting Plant, Phases I, II and III; USAEC Report TID-22330, Vols, 1 and 2, December 1965.

8. Spriggs, Theodore F. "Conceptual Design of a Man-Made Island for a Seawater Desalting and Power Plant", in Preprints: Offshore Technology Conference, 1971.

9. Bragg, D.M., Whitehorn, N.C. and Schmidt, B.D. An Evaluation of MultiPurpose Offshore Industrial/Port Islands for the Atlantic and Gulf Coasts: Market Demand and General Location Options, (Draft Report), prepared for NSF/RANN by Industrial Economics Research Division, Texas A \& M University, Jan. 1975.

10. Gilbert Assoclates, Inc. An Evaluation of Multi-Purpose Offshore Industrial/Port Islands for the Atlantic and Gulf Coasts: Process Description and Adaptation Study (Draft Report), prepared for NSF/RANN by Gilbert Assoclates, Inc., Jan. 1975.

11. Mangone, Gerald J. An Evaluation of Multi-Purpose Offshore Industrial/ Port Islands for the Atlantic and Gulf Coasts: Legal-Political Aspects (Draft Report), prepared for NSF/RANN by the Center for the Study of Marine Policy, College of Marine Studies, University of Delaware, Jan. 1975. 
12. Watling, L. An Evaluat ion of Mult1-Purpoge Offahore Industrta1/Port Iglands for the Atlantic and Gulf Coast-Environmental Assessment, (Draft Report), prepared for NSF/RANN by the College of Marine Studies, Untversity of Delaware, Jan. 1975.

13. "Imperlal's Drilling Island - So Far, So Good" The 011 and Gas Journal, v. 70, n. 43, p. 67, October 23, 1972.

14. Koffman, J.F. "Man-Made Islands Can Solve Many of our Problems", Ocean Industry, Feb. 1970 pp. 48-51.

15. "Artificlal Islands" Marine Pollution Bulletin, v. 5, August 1974, p. 113-114.

16. Soros, P. and Koman, B. "Artificial Island Trans-Shipment Terminal", in Preprints-0ffshore Technology Conference, Marine Technology Society, 1974 .

17. Costa, F.V., Allecasis, F.M. and deCampos, A.G., "Englneering and Economic Aspects of Offshore Structures for Unloading and Storing Goods," presented at XXXIIIrd International Navigation Conference, Ottawa, Canada, 1973.

18. B1d, "Building of Islands Urged for Recreation in Sound," New iork Times, November 29, 1974.

19. Seadun, Inc. and Camp Dresser \& McKee, Inc., Proposal for the Reclamation of Poplar Island in Chesapeake Bay Utillzing Baled Refuse Material, Nov. 1973.

20. McAleer, J. Artiflcial Islands and Platforms in Long Island Sound, New England River Basins Commission (undistributed draft report) 26 June 1974. See this report for its five mini-case studies of possible 1slands and facilitles in Long Island Sound, including estimates of costs.

21. Deepwater Port Policy Issues, Committee on Interjor and Insular Affalrs United States Senate, Serial No. 93-42-(92-77) 1974.

22. Tankers and the Marine Environment, Hearings before the National Ocean Policy Study Committee of Congress, U.S. Senate, Serial No. 94-7, Jan. 1975.

23. Much of the Information presented in this section has been gathered through personal communication with New Jersey PSE \& G personnel.

24. Council on Environmental Quality, offshore Nuclear Powerplant Study, U.S. Council on Environmental Quality, draft report, September 1974 (unpublished). 
25. Atlantic Generating Station Units Number 1 and 2, Plant and S1te Descriptions, New Jersey, Public Service Electrlc and Gas Company, August 1972 .

26. Lewis, L., Morell, D., unpublished draft report "Nuclear Power and Its Opponents: A New Jersey Case Study", Oct. 1976, Brookhaven National Laboratory.

27. The Federal Water Pollution Control Act, as amended (1972) P.L. 92500, sec. 316 (a).

28. "Thermal Discharges" Federal Register, v. 39 n. 196 pp 36176-36184, October $8,1974$.

29. A Survey of Unique Technical Features of the Floating Nuclear Power Plant Concept, U.S.A.E.C., Directorate of Licensing, March, 1974.

30. R. Nathan Associates, Inc, "U.S. Deepwater Port Study", Volumes I-IV, IWR-TR-8, August, 1972.

31. "The Economics of U.S. Deepwater Ports" - Final Report of the Energy Subcommittee Working Group on Deepwater Ports, in Einal Environmental Impact Statement - Deepwater Ports, Appendix B.

32. Deepwater Port Act of i)3-627 (1975).

33. See "Deepwater Ports: Proposed Rule-Making", U.S. Dept. of Transportation, Coast Guard, Federal Register, v. 40, n.89 (7 May 1975); and subsequent draft documents issued by the Coast Guard, including:

Environmental Review Criteria (proposed), 22 May 1975. Guide to Preparation of Environmental Analyses for Deepwater Ports (2nd draft), 6 May 1975;

Draft Environmental Impact Statement for Deepwater Port Regulations (2nd draft), 18 April, 1975; etc.

34. Jarvis, J. "Plans, plans, plans... but no refinery; Boston Globe, April 13, 1975.

35. Personal Communications with David A. O'Neil, PEPCO International, May 29, 1975.

36. van Dixthorn, J.; Meulenberg, M.; Terwindt, J.H.J.; Tutuarima, W.H.; Walther, A.W. and Stigter, C. "Recent Experience of Coastal Engineering Works in the Netherlands, with special emphas is on the use of sand and gravel," XXXIIIrd International Navigation Congress, Ottawa, 1972.

37. Regulatory Guide 4.7-General Site Suitabilicy Criteria for Nuclear Power Stations, U.S. AEC (1974). 
38. Regulatory Guide 1.70.7: Add1t Lonal Information, Geography and Demography Cons!derations for Nuclear Power Plants, U.S. AEC (1974).

39. General Environmental Siting Guides for Nuclear Power PlantB: Topics and Bases, (draft report) U.S. AEC (1973).

40. Slerra Club v. Ruckleshaus, 4ERC 1205.

41. "A1r Quality Implementation Plans: Prevention of Significant Deterioration", Federal Register, v. 39 n. 235 pp. $42510-42517$ (Dec. 5, 1974).

42. The reader is referred to the extenstve legal and policy literature on the Price-Anderson Act and other federal initiatives to develop nuclear power for energy purposes.

43. See Sclence, v. (4 July 1975), Pp. 29-30 for article "Nuclear Power: WegtInghouse Looks to Washington for a Customer".

44. Some of these considerations are addressed in the companton volume to this study: Backstrom, T. D, and Baram, M., "Artificlal Islands for Cluster Siting of Offshore Energy Facilitles: An Assessment of the Legal and Regulatory Framework", BNL-50566 (June 1976). 